
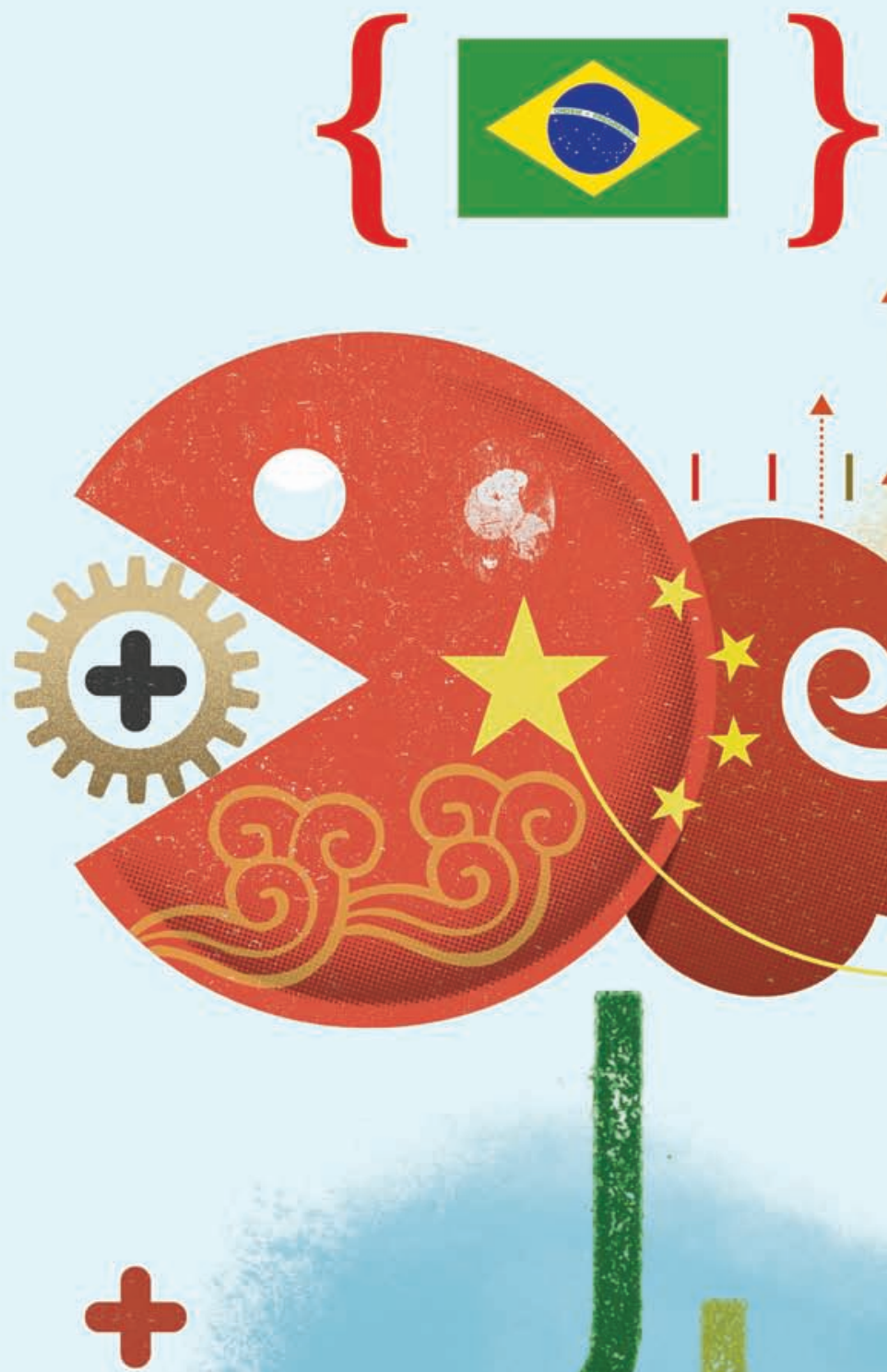

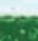
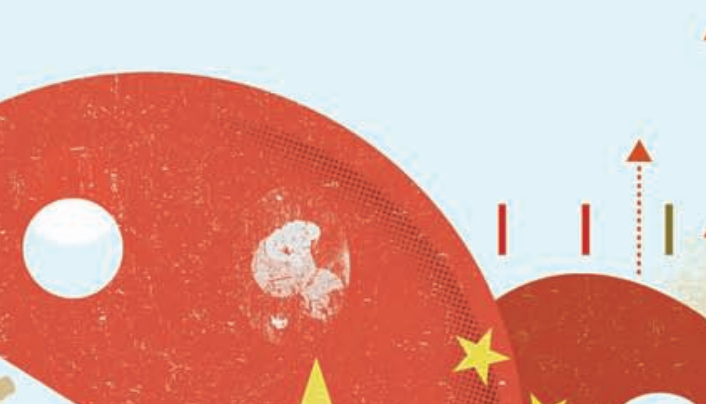


\title{
Brasil-China: um negócio da China ou para a China?
}

\author{
Brazil-China: a deal from China or to China?
}

\author{
* Antônio Mórcio Buoinain \\ ** Pedro Abel Vieira Junior
}

\begin{abstract}
Resumo
O crescimento das relações comerciais entre Brasil e China nesta primeira década do Século XXI foi espetacular; configurou-se uma clara especialização assimétrica, na qual o Brasil exporta principalmente matérias primas agropecuárias e minerais e importa bens manufaturados de baixa e média intensidade tecnológica. $\mathrm{O}$ artigo sustenta que esta especialização não é, em si, ruim, pois um país da dimensão e com os recursos do Brasil deve explorar e aproveitar todas as oportunidades de geração de riqueza. Os chineses são compradores de soja, algodão, minério de ferro - produtos nos quais o Brasil é competitivo - e não de óleo de soja, têxteis e ferro. Estas exportações de cadeias produtivas importantes abrem oportunidades para a realização de bons negócios, da China, também para o Brasil, e não apenas para a China. A viabilidade destes negócios depende mais da política do que do mercado, mas só se concretizarão se a política não violentar o mercado.
\end{abstract}

Palavras-chave: Comércio Agrícola Brasil-China; Agronegócio ; Exportações Agrícolas.

\begin{abstract}
The growth of Brazilian - China trade relations during the first decade of XXI century was remarkable. Brazil has become a major exporter of agricultural and mineral commodities whereas China exports manufactured goods of low and medium technological intensity. The paper argues that though asymmetric, this specialization is not negative or positive by itself. Brazil must explore and grasp every opportunity to generate wealthy; the Chinese are demanding commodities and meeting their needs opens business opportunities that can benefit both China and Brazil in a more balanced way than current trade trend. This requires trade and diplomatic negotiations and the challenge is to carry on these negotiations without violating the market relations.
\end{abstract}

Keywords: Brazil-China Trade Relations in Agriculture; Agribussiness; Agricultural Exports.

\footnotetext{
* Professor do Instituto de Economia da Universidade Estadual de Campinas, Pesquisador do Instituto Nacional de Ciência e Tecnologia em Políticas Públicas, Estratégias e Desenvolvimento (INCT-PPED).

E-mail: buainain@gmail.com

** Pesquisador da Embrapa Estudos e Capacitação.

E-mail: pedro.vieira@embrapa.br
} 


\section{Introdução}

Wos últimos anos as relações Brasil - China tiveram um crescimento extraordinário, com impactos significativos na economia brasileira. $O$ crescimento do comércio é a face mais visível desta aproximação, que, no entanto, se estende para o campo das alianças políticas e tecnológicas e pela busca conjunta de liderança no cenário global. As relações sino brasileiras são marcadas por convergências e divergências, por complementariedades e concorrência, por cooperação e por disputas em todos os campos, revelando tanto uma gigantesca complexidade que está exigindo da diplomacia brasileira um aprendizado rápido, consistente e dinâmico, como grandes oportunidades de ganhos para ambos os lados que ainda parecem longe de se realizar plenamente.

A própria emergência da China como grande potência econômica foi fator decisivo para a transformação, nas últimas duas décadas, do comércio internacional e da mudança, pelo menos temporária, do paradigma dos termos de troca desfavoráveis para países exportadores de commodities agropecuárias e minerais. Os termos das questões globais mais prementes - segurança energética e alimentar, inovação tecnológica, mudanças climáticas e o próprio ordenamento mundial - estão sendo inteiramente revistos à luz da emergência chinesa, cuja história multimilenar não fornece suficiente informação para decifrar com facilidade o que poderia ser chamado de "enigma chinês". Decifrar esse enigma é fundamental, pois os países e empresas que não compreenderem os rumos da China e não forem capazes de tecer alianças e parcerias estarão certamente perdendo "negócios da China'."

A importância e a profundidade do vínculo comercial bilateral são inegáveis, mas é preciso qualificar o debate atual sobre a ameaça e oportunidade que a China representa à luz da evolução recente. Já não se discute muito sobre a especialização da corrente comercial Brasil - China, com o Brasil exportando produtos primários, sem ou com baixa agregação de valor, e importando manufatura chinesa, com nível crescente de conteúdo tecnológico. Esta "especialização assimétrica" é hoje um dado da realidade, que parece difícil reverter. A questão que se coloca é em que medida o Brasil pode aproveitar esta realidade como alavanca para seu próprio desenvolvimento.

Uma diferença fundamental entre os dois países é que a China tem e segue um plano de desenvolvimento nacional bem definido, com objetivos estratégicos, metas, meios e responsabilidades, o qual considera as dimensões do crescimento econômico, com a participação dos vários setores, criação de emprego para absorver a população em movimento do campo para as cidades, a segurança alimentar e energética e a autonomia e soberania em todas as áreas chaves. No contexto de um regime político forte e que confere poder de enforcement ao aparelho de Estado, as políticas públicas, o mercado e as relações internacionais são condicionadas e guiadas pelos objetivos de desenvolvimento. Ou seja, a inserção econômica e comercial da China na economia global é fortemente moldada pelo que se poderia chamar, genericamente, 
de "interesses nacionais", definidos nos planos e ou nas sublinhas determinadas pela história, cultura e instituições vigentes.

O modelo chinês é, portanto, bem distinto do brasileiro, cuja inserção no cenário global tem sido guiada fundamentalmente pelo mercado, a partir de oportunidades percebidas, criadas e aproveitadas pelo setor privado, com baixa ou nenhuma participação positiva do governo e/ou das políticas públicas.

Desta maneira, apesar de discursos, declarações das autoridades dos dois países, assinatura de protocolos e acordos de cooperação nos mais diversos campos, as relações sino brasileiras foram se formando a partir de racionalidades e motivações diferenciadas - uma pautada e dirigida pelo Estado e outra pelos mercados -, com os interesses chineses criando oportunidades de mercado que vêm sendo aproveitadas pelo setor privado brasileiro como "negócios da China". Porém, a falta de coordenação das iniciativas pelo setor público e de mecanismos para estimular sinergias e gerar convergência entre os interesses privados e os "interesses nacionais", o atual "negócio da China" pode se revelar mais um "negócio para a China".

Um condicionante importante que vem moldando a estratégia chinesa é a busca de segurança estratégica em áreas nas quais tem elevada dependência, como a alimentar e energética. A China é o maior produtor de alimentos no mundo e ainda assim depende de importações para atender a demanda local; a China é também o maior consumidor mundial de trigo, soja e arroz, e o segundo maior consumidor de milho. Além disso, a dependência externa é concentrada em alguns produtos, com destaque para soja e produtos lácteos, cujo consumo doméstico vem crescendo sem ser acompanhado pela produção. $O$ crescimento da demanda chinesa vem colocando pressão sobre a produção global e criando oportunidades de negócios para os países exportadores. $\mathrm{O}$ caso mais claro é o da soja, produto cujas importações da China já representam quase $65 \%$ do total importado no mundo. Por outro lado, o consumo de alguns produtos está estagnado, refletindo as mudanças nos hábitos de consumo, é o caso do trigo e do arroz, itens que a China é praticamente autossuficiente.

Apesar da crescente dependência, a China não descuida da soberania alimentar e dos demais condicionantes e objetivos de desenvolvimento local, desde a escassez de água até a ocupação de mão-de-obra no meio rural. Estas preocupações se refletem nas políticas públicas, seja na proteção e apoio à agricultura e agroindústria local - o que determina a importação de grãos em detrimento da aquisição de carnes e lácteos e a imposição de barreiras para frutas, açúcar e madeira - seja na diversificação das fontes de abastecimento, incentivando e apoiando países da África e vizinhos asiáticos a expandir a produção e/ou adquirindo terras no estrangeiro para produção de alimentos e energia por empresas chinesas.

Neste contexto, as relações entre o Brasil e a China na área da agricultura, antes de um problema, oferecem grandes oportunidades para o Brasil expandir os fluxos comerciais e financeiros e consolidar a estruturação de cadeias produtivas do 
agronegócio com competitividade para se tornar, de fato, um dos principais produtores e exportadores de alimentos do mundo.

No entanto, a especialização em grãos e produtos in natura e o peso crescente do mercado chinês nas exportações brasileiras indica a necessidade de ativar políticas de precaução que reduzam os riscos de intervenções políticas nos mercados globais de alimentos que poderiam ser exercidas por um comprador com a dimensão da China, cujo regime permite um elevado nível de controle sobre as decisões dos agentes que atuam nos mercados. Da mesma maneira que a China tem buscado diversificar as fontes de abastecimento, o Brasil depende tanto do mercado interno como da diversificação de seus clientes internacionais para manter a sustentabilidade do desenvolvimento baseado no agronegócio. Em certo sentido, o comércio com a China representa mais que uma simples e rentável oportunidade comercial; representa 'a' oportunidade de consolidar um eixo importante de desenvolvimento do país, financiar a implantação da infraestrutura, que hoje representa um sério entrave para a competitividade geral e do agronegócio em particular, colocar a inovação como motor do crescimento sustentável e de evoluir na sustentabilidade socioambiental e institucional. Isto requer um esforço doméstico para qualificar a economia e o agronegócio brasileiro para competir em todos os mercados mundiais e para reduzir a dependência da China e de condições excepcionais nos mercados de matérias-primas minerais e agropecuárias criadas pela demanda chinesa.

\section{A China no mundo: abrindo oportunidades e ocupando espaços}

O modelo econômico do "socialismo chinês"2", reformado por Deng Xiaoping a partir da década de 1980 colocou a China em uma rota de crescimento acelerado que em duas décadas transformou o país na segunda maior economia do mundo e criou um novo mercado consumidor de aproximadamente 350 milhões de pessoas que deixaram a pobreza (Gráfico 1).

As transformações estruturais, principalmente a rápida urbanização e a industrialização do país, e o crescimento acelerado da China, com elevação da renda real $^{3}$ e redução da pobreza (Gráfico 1), implicaram no significativo aumento no consumo de produtos agrícolas. Os investimentos em infraestrutura, a política de crédito e as reformas do socialismo chinês, mais focalizados no fortalecimento do mercado interno, indicam que a demanda por alimentos continuará crescendo nos próximos anos, até por necessidade de reduzir tensões sociais com potencial de criar fissuras e fragilizar o regime político.

Entre 1990 e 2010 as exportações totais da China cresceram (Gráfico 2) 9,1\% a.a. e as importações $9,4 \%$ a.a. enquanto as do Brasil cresceram, respectivamente, 9,1 e 1,9\% a.a. Este desempenho colocou a China como um dos motores da economia mundial, elevou sua participação no mercado mundial de menos de $2 \%$ para 
$10 \%$ do total das exportações e $9 \%$ das importações, enquanto ambos os fluxos do Brasil permaneceram abaixo de 1,5\%.

A China se tornou um grande agente no comércio mundial, com capacidade de afetar significativamente o mercado de produtos básicos, com destaque para produtos agrícolas e minerais, e o mercado de manufaturas, com destaque para ferro e aço, máquinas, roupas e têxteis. Essa dinâmica chinesa deve ser reforçada nas próximas décadas, notadamente no que diz respeito aos produtos básicos, mas avançando também em segmentos de maior conteúdo tecnológico, desde eletrônicos, automobilística, máquinas, ferramentas até trens de alta velocidade e satélites. Também se tornou um player importante na esfera financeira, deslocando os países árabes petroleiros como principal financiador do déficit externo americano e um investidor que já tem um peso significativo nos países em desenvolvimento e mais pobres, e que também vem se expandindo nos países desenvolvidos.

Gráfico 1 - Participações (\%) do Brasil e da China no PIB mundial (PIB) e \% da população vivendo com menos de US\$ por dia (Pobreza) entre os anos de 1990 a 2010 e as respectivas taxas de crescimento anualizadas (\% a.a.) (World Bank, 2012).
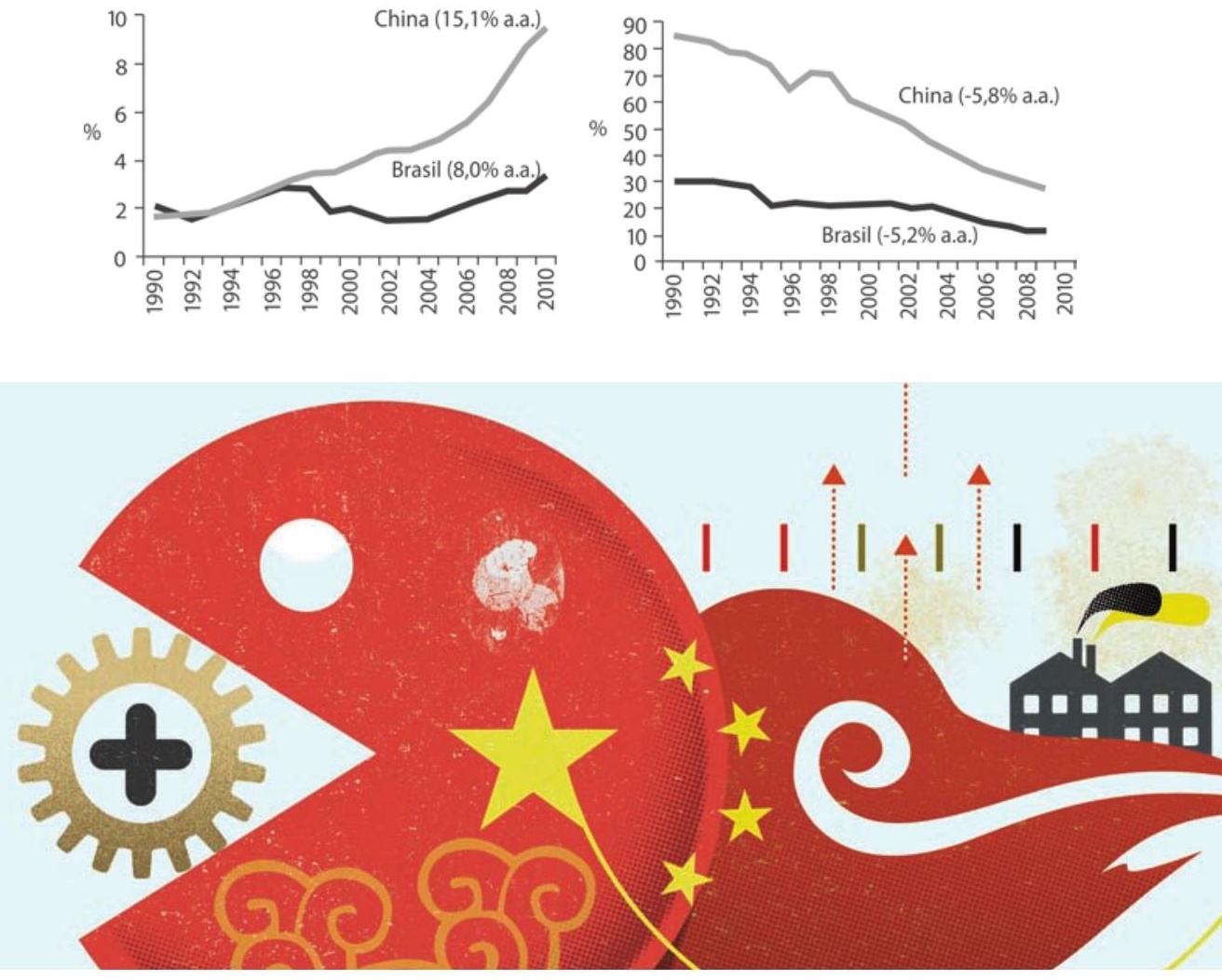
Neste contexto, o crescimento da China tem criado muitas oportunidades para o crescimento de muitos países, como o Brasil. Ao lado destas oportunidades, a China também se coloca como um concorrente tanto nos mercados domésticos como nos mercados dos países desenvolvidos, ocupando espaço principalmente no suprimento de produtos manufaturados. Também vem ocupando espaço crescente na geopolítica mundial, a exemplo de sua participação na solução da atual crise europeia, com cada vez mais poder de barganha tanto comercial quanto político.

Gráfico 2 - Participações (\%) mundiais das importações e exportações totais e de serviços do Brasil e da China entre os anos de 1990 a 2010 e as respectivas taxas de crescimento anualizadas (\% a.a.) (World Bank, 2012).

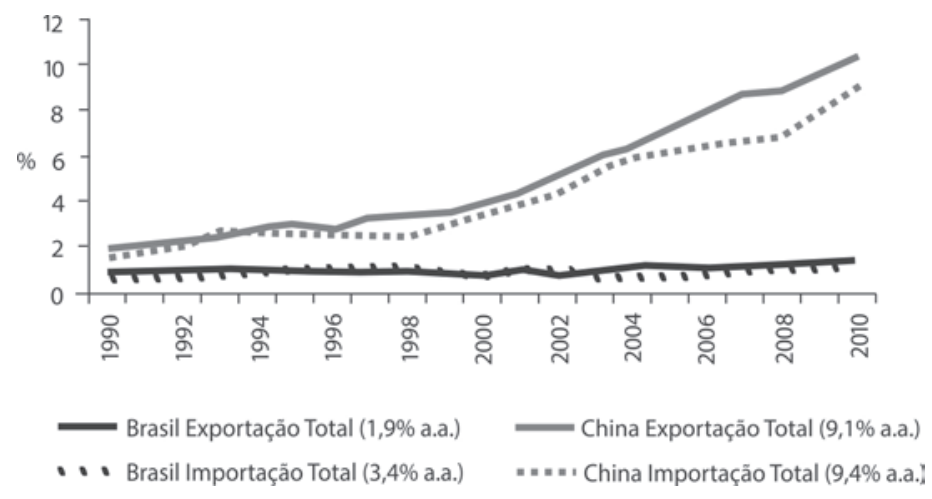

\section{Comércio exterior: a especialização assimétrica}

O crescimento experimentado pela economia chinesa nas duas últimas décadas se traduziu em aumento do seu comércio externo com o resto do mundo 4 e com o Brasil. O comércio bilateral Brasil-China se multiplicou mais de 100 vezes entre 1990 e 2010, e neste último ano ultrapassou US\$ 62 bilhões e representou 34\% do comércio da China com a América Latina e mais de $50 \%$ do comércio externo brasileiro. A evolução do comércio entre o Brasil e a China registrou períodos distintos no decorrer das últimas décadas (Tabela 1), ora com saldos favoráveis ao Brasil ora à China. Na primeira metade da década de 1990 o saldo foi positivo para o Brasil, inverteu-se no período 1996-2000 em favor da China, e depois de alguns anos de superávit voltou a ser negativo em 2007 e 2008 e desde 2009 tem sido favorável ao Brasil. Neste período a China tornou-se o parceiro comercial mais importante do Brasil: em 1990 representava apenas 1,3\% do comércio externo e em 2011 a China absorveu mais de 16\% das vendas externas do Brasil e se transformou no principal destino das exportações brasileiras e o país do qual o Brasil mais importa. As projeções indicam que essa tendência será mantida no futuro (BACEN, 2011). 
Tabela 1 - Fluxo comercial do Brasil com a China entre os anos 1990 a 2010 (MDIC, 2012).

\begin{tabular}{|c|c|c|c|c|c|c|c|}
\hline Ano & Exportação & & Importação & & Saldo & Corrente & Cobertura \\
\hline & US\$* & $(\%)^{* *}$ & US\$* & $(\%)^{* *}$ & $(A-B)$ & $(A+B)$ & $(\mathrm{A} / \mathrm{B})$ \\
\hline 1990 & 381.804 & 1,2 & 168.792 & 0,8 & 213.012 & 550.596 & 2,3 \\
\hline 1995 & 1.203 .751 & 2,6 & 1.041 .728 & 2,1 & 162.022 & 2.245 .479 & 1,2 \\
\hline 2000 & 1.085 .302 & 2,0 & 1.222 .098 & 2,2 & -136.797 & 2.307 .400 & 0,9 \\
\hline 2005 & 6.834 .997 & 5,8 & 5.354 .519 & 7,3 & 1.480 .478 & 12.189 .516 & 1,3 \\
\hline 2006 & 8.402 .369 & 6,1 & 7.990 .448 & 8,8 & 411.920 & 16.392 .817 & 1,1 \\
\hline 2007 & 10.748 .814 & 6,7 & 12.621 .273 & 10,5 & -1.872 .460 & 23.370 .087 & 0,9 \\
\hline 2008 & 16.522 .652 & 8,4 & 20.044 .461 & 11,6 & -3.521 .808 & 36.567 .113 & 0,8 \\
\hline 2009 & 21.003 .886 & 13,7 & 15.911 .134 & 12,5 & 5.092 .753 & 36.915 .020 & 1,3 \\
\hline 2010 & 30.785 .906 & 15,3 & 25.595 .419 & 14,1 & 5.190 .487 & 56.381 .325 & 1,2 \\
\hline$\%$ a.a. & 24,5 & 13,4 & 28,5 & 15,2 & 17,3 & 26,1 & $-3,1$ \\
\hline
\end{tabular}

*1.000 US\$ FOB; ** Participação da China nas exportações e importações brasileiras.

O espetacular crescimento do volume do comércio Brasil-China conta apenas parte da estória: as mudanças na pauta e no conteúdo tecnológico é que revelam a "divisão de trabalho e especialização" que se formou nas duas últimas décadas e já se cristalizou nos últimos anos: o Brasil como exportador de commodities minerais e agropecuárias e a China como exportadora de manufatura de médio conteúdo tecnológico. Além disso, enquanto as exportações brasileiras para a China se "especializaram" as exportações da China para o Brasil e para o mundo se diversificaram com a incorporação de produtos manufaturados de média densidade tecnológica sem, no entanto, perder a presença significativa que já tinha nas exportações mundiais de produtos agrícolas e minerais.

Em termos de valor agregado o comércio externo brasileiro seguiu direção contrária à trajetória chinesa, com a redução das exportações e o aumento das importações de maior valor agregado: nos últimos anos cresceram as exportações brasileiras de matérias-primas minerais e agrícolas e as importações de manufaturas, enquanto o comércio chinês registrou movimento inverso.

Essa dinâmica do comércio internacional refletiu-se na participação dos dois países no mercado mundial. A China tornou-se grande importador mundial em todos os segmentos, com ênfase nos produtos básicos ${ }^{5}$ e combustíveis, enquanto o Brasil adquiriu um perfil exportador de produtos básicos e importador de manufaturas. Mas, apesar do crescimento das exportações de básicos, o Brasil não ganhou importância no comércio mundial de produtos básicos ${ }^{6}$ e muito menos no de manufaturas.

Ressalta-se que os dez principais produtos exportados pelo Brasil para a China representaram mais de $85 \%$ de todos os bens que o Brasil exportou para esse país em 2010 enquanto as importações brasileiras, além de maior conteúdo tecnológico, são mais diversificadas (Tabela 2). Além disso, como indica Rosales (2012), a posição do Brasil como fornecedor da China tem se reduzido, tanto quantitativamente (Gráfico 3) como qualitativamente (Tabela 2), com aumento da concorrência e várias oportunidades perdidas (Tabela 3). 
Tabela 2 - Participações (\%) de produtos básicos (Basi), semimanufaturados (Semi) e manufaturados (Manu) exportados e importados pelo Brasil à China entre 1990 a 2010 e as respectivas taxas de crescimento anuais (MDIC, 2012).

\begin{tabular}{|l|l|l|l|l|r|l|}
\hline Ano & \multicolumn{4}{l}{ Exportações } & \multicolumn{2}{l|}{ Importações } \\
\hline & Basi & Semi & Manu & \multicolumn{1}{l}{ Basi } & \multicolumn{1}{l|}{ Semi } & Manu \\
\hline 1990 & 19,62 & 48,85 & 31,52 & 65,06 & 20,00 & 14,94 \\
\hline 1995 & 15,90 & 57,25 & 26,83 & 21,90 & 7,71 & 70,38 \\
\hline 2000 & 68,16 & 12,97 & 18,77 & 8,23 & 1,34 & 90,43 \\
\hline 2005 & 68,38 & 14,70 & 16,69 & 4,59 & 1,26 & 94,15 \\
\hline 2006 & 73,95 & 15,18 & 10,47 & 10,82 & 1,14 & 88,04 \\
\hline 2007 & 73,75 & 18,02 & 8,07 & 2,55 & 0,73 & 96,72 \\
\hline 2008 & 77,65 & 15,65 & 6,63 & 4,31 & 0,53 & 95,16 \\
\hline 2009 & 77,66 & 15,53 & 6,77 & 1,61 & 0,27 & 98,12 \\
\hline 2010 & 83,66 & 11,77 & 4,53 & 2,09 & 0,41 & 97,49 \\
\hline$\%$ a.a. & 7,52 & $-6,87$ & $-9,24$ & $-15,79$ & $-17,68$ & 9,83 \\
\hline
\end{tabular}

Tabela 3 - Variação da participação brasileira nas importações chinesas*(Brasil, \%), variação das importações chinesas* (China, \%a.a.), Categoria estelar** (Estrela) e os três principais concorrente do Brasil (Concorrente) nos 34 principais capítulos exportados pelo Brasil entre os anos de 2000 a 2010 (CNI, 2011).

\begin{tabular}{|c|c|c|c|c|}
\hline Capítulo & Brasil & China & Estrela & Concorrentes \\
\hline BRASIL & 1,3 & 19,0 & - & \\
\hline $\begin{array}{l}\text { Produtos } \\
\text { Selecionados }\end{array}$ & 2,9 & 28,3 & - & \\
\hline Açúcar & 64,4 & 28,4 & Nascente & Brasil (64\%), Cuba (29\%) e Austrália (3\%) \\
\hline $\begin{array}{l}\text { Pedaços e miudezas } \\
\text { de aves }\end{array}$ & 55,9 & 12,1 & Nascente & Brasil (58\%), Argentina (25\%) e EUA (14\%) \\
\hline $\begin{array}{l}\text { Semimanufaturados } \\
\text { de ferro/aço }\end{array}$ & 44,2 & $-20,9$ & Minguante & Brasil (68\%), Rússia (13\%) e Japão (8\%) \\
\hline Óleo de soja & 43,2 & 2,9 & Nascente & Brasil (67\%), EUA (21\%) e Argentina (11\%) \\
\hline $\begin{array}{l}\text { Pasta de madeira } \\
\text { conífera }\end{array}$ & 26,2 & 34,5 & Nascente & Brasil (30\%), Canadá (21\%) e EUA (15\%) \\
\hline Sucos de laranjas & 17,5 & 7,0 & Nascente & Brasil (81\%), Israel (13\%) e EUA (5\%) \\
\hline Granito & 15,1 & 6,7 & Nascente & $\begin{array}{l}\text { Arábia Saudita (42\%), Brasil (31\%) e Índia } \\
(10 \%)\end{array}$ \\
\hline $\begin{array}{l}\text { Fumo não } \\
\text { manufaturado }\end{array}$ & 14,4 & 15,2 & Nascente & Brasil (48\%), EUA (22\%) e Zimbábue (16\%) \\
\hline $\begin{array}{l}\text { Pasta de madeira não } \\
\text { conífera }\end{array}$ & 13,0 & 17,3 & Nascente & $\begin{array}{l}\text { Brasil (40\%), Indonésia (22\%) } \\
\text { e Uruguai }(9 \%)\end{array}$ \\
\hline Ferro fundido bruto & 7,0 & 24,7 & Nascente & $\begin{array}{l}\text { Rússia (30\%), Coréia do Norte (17\%) } \\
\text { e Ucrânia (16\%) }\end{array}$ \\
\hline Ferronióbio & 5,9 & 47,9 & Nascente & Brasil (94\%) e Canadá (6\%) \\
\hline $\begin{array}{l}\text { Couros e peles } \\
\text { inteiros }\end{array}$ & 5,0 & 2,0 & Nascente & $\begin{array}{l}\text { Itália (34\%), Brasil (16\%) } \\
\text { e Coréia do Sul (10\%) }\end{array}$ \\
\hline
\end{tabular}


Tabela 3 (cont.) - Variação da participação brasileira nas importações chinesas*(Brasil, \%), variação das importações chinesas* (China, \%a.a.), Categoria estelar** (Estrela) e os três principais concorrente do Brasil (Concorrente) nos 34 principais capítulos exportados pelo Brasil entre os anos de 2000 a 2010 (CNI, 2011).

\begin{tabular}{|c|c|c|c|c|}
\hline Capítulo & Brasil & China & Estrela & Concorrentes \\
\hline $\begin{array}{l}\text { Couros e peles } \\
\text { curtidos }\end{array}$ & 4,6 & 28,0 & Nascente & EUA (30\%), Brasil (27\%) e Vietnã (7\%) \\
\hline $\begin{array}{l}\text { Aviões e veículos } \\
\text { aéreos }\end{array}$ & 3,4 & 17,0 & Nascente & EUA (48\%), França (29\%) e Alemanha (19\%) \\
\hline $\begin{array}{l}\text { Óleos brutos de } \\
\text { petróleo e minerais }\end{array}$ & 3,0 & 31,5 & Nascente & $\begin{array}{l}\text { Arábia Saudita (19\%), Angola (17\%) } \\
\text { e Irã (9\%) }\end{array}$ \\
\hline Algodão bruto & 2,1 & 25,4 & Nascente & EUA (35\%), Índia (31\%) e Uzbequistão (12\%) \\
\hline $\begin{array}{l}\text { Minérios de } \\
\text { manganês }\end{array}$ & 2,0 & 45,2 & Nascente & $\begin{array}{l}\text { Austrália (32\%), África do Sul (27\%) e } \\
\text { Gabão (14\%) }\end{array}$ \\
\hline Soja, mesmo triturada & 1,4 & 24,5 & Nascente & EUA (45\%), Brasil (32\%) e Argentina (20\%) \\
\hline $\begin{array}{l}\text { Cátodos de cobre e } \\
\text { seus elementos }\end{array}$ & 0,6 & 36,8 & Nascente & Chile (47\%), Japão (8\%) e Cazaquistão (6\%) \\
\hline $\begin{array}{l}\text { Partes de motores } \\
\text { ignição }\end{array}$ & $-0,1$ & 12,2 & $\begin{array}{l}\text { Oportunidade } \\
\text { perdida }\end{array}$ & $\begin{array}{l}\text { Japão ( } 46 \%) \text {, Alemanha ( } 21 \%) \text { e Coréia do } \\
\text { Sul }(11 \%)\end{array}$ \\
\hline $\begin{array}{l}\text { Minérios de ferro não } \\
\text { aglomerados }\end{array}$ & $-2,4$ & 51,6 & $\begin{array}{l}\text { Oportunidade } \\
\text { perdida }\end{array}$ & Austrália (45\%), Brasil (22\%) e Índia (15\%) \\
\hline $\begin{array}{l}\text { Couros e peles não } \\
\text { curtidos }\end{array}$ & $-2,4$ & 12,1 & $\begin{array}{l}\text { Oportunidade } \\
\text { perdida }\end{array}$ & $\begin{array}{l}\text { Argentina (30\%), Brasil (22\%) } \\
\text { e Tailândia (13\%) }\end{array}$ \\
\hline $\begin{array}{l}\text { Laminados de ferro/ } \\
\text { aço }\end{array}$ & $-2,9$ & $-24,5$ & Retrocesso & $\begin{array}{l}\text { Japão (57\%), Asiáticos (27\%) } \\
\text { e Cazaquistão (7\%) }\end{array}$ \\
\hline $\begin{array}{l}\text { Outros laminados de } \\
\text { ferro/aço }\end{array}$ & $-3,4$ & $-4,1$ & Retrocesso & $\begin{array}{l}\text { Japão (47\%), Coréia do Sul (25\%) } \\
\text { e Asiáticos ( } 22 \%)\end{array}$ \\
\hline $\begin{array}{l}\text { Outros papéis e } \\
\text { cartões }\end{array}$ & $-3,6$ & $-23,9$ & Retrocesso & $\begin{array}{l}\text { Coréia do Sul (24\%), Indonésia (20\%) } \\
\text { e China (13\%) }\end{array}$ \\
\hline Outras madeiras & $-5,0$ & 12,5 & $\begin{array}{l}\text { Oportunidade } \\
\text { perdida }\end{array}$ & Tailândia (37\%), EUA (16\%) e Rússia (8\%) \\
\hline $\begin{array}{l}\text { Motores de pistão } \\
\text { alternativo }\end{array}$ & $-5,5$ & 23,0 & $\begin{array}{l}\text { Oportunidade } \\
\text { perdida }\end{array}$ & $\begin{array}{l}\text { Japão (33\%), Hungria (27\%) } \\
\text { e Alemanha }(20 \%)\end{array}$ \\
\hline $\begin{array}{l}\text { Níquel bruto não } \\
\text { ligado }\end{array}$ & $-6,3$ & 30,6 & $\begin{array}{l}\text { Oportunidade } \\
\text { perdida }\end{array}$ & $\begin{array}{l}\text { Rússia (39\%), Canadá (18\%) } \\
\text { e Austrália (17\%) }\end{array}$ \\
\hline $\begin{array}{l}\text { Laminados de ferro/ } \\
\text { aço não ligados }\end{array}$ & $-6,6$ & $-4,1$ & Retrocesso & $\begin{array}{l}\text { Coréia do Sul (46\%), Japão (30\%) } \\
\text { e Asiáticos (10\%) }\end{array}$ \\
\hline $\begin{array}{l}\text { Partes e acessórios } \\
\text { para automóveis }\end{array}$ & $-8,3$ & 1,3 & $\begin{array}{l}\text { Oportunidade } \\
\text { perdida }\end{array}$ & $\begin{array}{l}\text { Japão ( } 43 \%) \text {, Alemanha (31\%) } \\
\text { e Coréia do Sul (8\%) }\end{array}$ \\
\hline Madeiras tropicais & $-10,9$ & $-3,5$ & Retrocesso & $\begin{array}{l}\text { Indonésia (26\%), Myanmar (17\%) } \\
\text { e Brasil (12\%) }\end{array}$ \\
\hline $\begin{array}{l}\text { Semimanufaturados } \\
\text { de ferro/aço não } \\
\text { ligados }\end{array}$ & $-13,5$ & $-27,1$ & Retrocesso & Japão (67\%), Rússia (20\%) e Cingapura (5\%) \\
\hline Minérios de ferro & $-14,0$ & 25,2 & $\begin{array}{l}\text { Oportunidade } \\
\text { perdida }\end{array}$ & $\begin{array}{l}\text { Brasil (30\%), Cazaquistão (14\%) e } \\
\text { Ucrânia (10\%) }\end{array}$ \\
\hline $\begin{array}{l}\text { Outros } \\
\text { semimanufaturados } \\
\text { de ferro/aço }\end{array}$ & $-15,1$ & $-21,5$ & Retrocesso & $\begin{array}{l}\text { Alemanha (38\%), Coréia do Norte (21\%) } \\
\text { e Japão }(19 \%)\end{array}$ \\
\hline
\end{tabular}

* Participação \% no total importado em 2010.

**A análise do desempenho 'estelar' foi proposta pela CEPAL e permite estimar o dinamismo entre dois países a partir da evolução da participação do país no mercado e da evolução desse mercado. Para tanto, foram considerados as variações, por capitulo, do total de importações chinesas (Importações) e das exportações brasileiras para a China (Exportações) entre os anos de 2000 a 2010 classificando os capítulos em Nascentes (Importação crescente e Exportação crescente), Minguantes (Importação decrescente e Exportação crescente), Retrocesso (Importação decrescente e Exportação decrescente) e Oportunidade perdida (Importação crescente e exportação decrescente).ráfico 3. Participaçẫo (\%) brasileira nas importaçôes chinesas de produtos básicos, manufaturados e bens de capital entre os anos de 1995 a 2010 e as respectivas taxas de crescimento anualizadas (OCDE, 2012 e CNI, 2011). 
Gráfico 3 - Participação (\%) brasileira nas importações chinesas de produtos básicos, manufaturados e bens de capital entre os anos de 1995 a 2010 e as respectivas taxas de crescimento anualizadas (OCDE, 2012 e CNI, 2011).

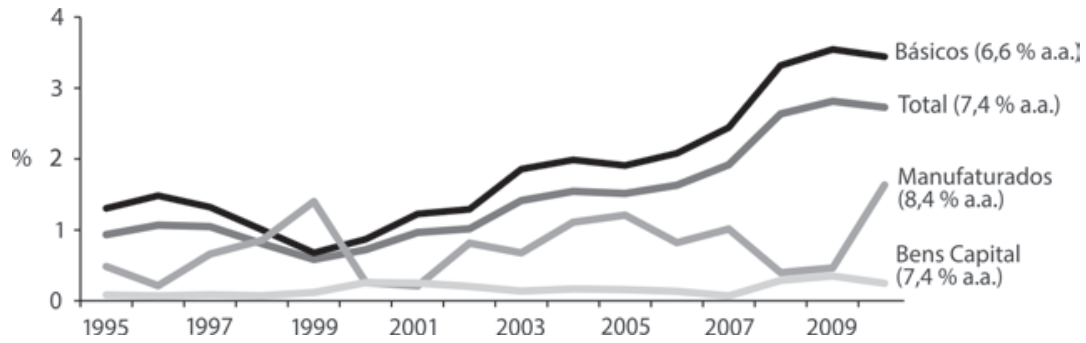

O comércio sino-brasileiro não parece sofrer forte influência de barreiras tarifárias. Os 10 principais produtos exportados pelo Brasil não são objetos de tarifas elevadas por parte da China ${ }^{7}$, e a imposição de tarifas mais elevadas pelo Brasil (20\% ) sobre a importação de alguns produtos chineses - notadamente têxteis e brinquedos - é mais uma reação ao forte crescimento das importações que uma barreira propriamente dita (Mortatti, 2009).

As alíquotas, que indicam a liberalização comercial, escondem uma realidade inconveniente. A despeito da entrada da China na OMC em 2001 e da redução de várias medidas protecionistas, como por exemplo o corte de $140 \%$ para $2,4 \%$ na tarifa aplicada à soja definido pelo World Integrated Trade Solution em 2008, a influência de empresas estatais chinesas como a China National Cereals, Oils and Food stuffs Import and Export Company (COFCO), principalmente de commodities agrícolas, marca fortemente a dinâmica do comércio externo da China. Assim, apesar do protocolo de acesso à OMC limitar as influências dessas estatais, a COFCO ainda tem grande poder de controle sobre as exportações e as importações de diversos produtos agrícolas (Mccorriston e Maclauren, 2007), o que afeta diretamente as exportações brasileiras ${ }^{8}$.

Apesar das baixas barreiras tarifárias, muitas práticas continuam a distorcer o comércio exterior chinês, como por exemplo, a quarentena sanitária aplicada pela China por base em evidências científicas frágeis e regulamentos questionáveis (MIDIC, 2008, apud, Mortatti, 2009). Ou seja, apesar das reduções tarifárias e da abertura comercial, ainda existem dificuldades potenciais para o brasileiro vender ao chinês ${ }^{9}$.

A pauta de exportação brasileira, em termos de produtos, é relativamente concentrada em matérias-primas e artigos do agronegócio. No passado, o Brasil também exportou carros e aviões, que somados representaram apenas $5 \%$ da pauta em $2010 .{ }^{10}$ (Rosales, 2012). Romper com a especialização que se delineou na última década depende menos do "mercado" e mais da política para moldar acordos estratégicos e soberanos que assegurem o fornecimento de alimentos e matérias-primas para a 
China e em contrapartida abram também espaço para exportações de manufaturados e produtos de maior intensidade tecnológica. Se do lado da China a participação de estatais e o dirigismo econômico permitem fazer acordos sobre a pauta comercial, do lado do Brasil a situação é bem mais complexa, uma vez que as exportações que seriam negociadas dependem, fundamentalmente, do setor privado.

A complementariedade das balanças comerciais sino-brasileiras, as possibilidades de ampliar as relações comerciais na base desta especialização assimétrica já vigente e as vantagens competitivas na produção de matérias-primas não significa que a posição do Brasil está assegurada. De um lado, a China tem uma estratégia clara de diversificação dos parceiros internacionais e sua importância e poder de barganha no comércio internacional só tendem a crescer. Do outro, o Brasil conquistou a atual posição a despeito da ineficiência sistêmica em um contexto de preços internacionais excepcionalmente elevados, e a manutenção desta posição depende da realização dos investimentos e reformas domésticas para superar os gargalos estruturais que reduzem a competitividade das empresas brasileiras.

Em que pesem as assimetrias, as relações comerciais sino-brasileiras ainda tem muito a avançar com a adoção, pelos dois países, de estratégias pautadas pelos interesses próprios de cada um. O Brasil tem muitas oportunidades, as quais, permeadas de ameaças, tornam as relações complexas e desfavoráveis ao país. Se há 25 anos o Brasil tinha força para se impor diante da China; hoje é o contrário e a China tem condições de impor suas prioridades ao Brasil, com pouca margem de manobra para negociar termos diferentes. Os mercados e oportunidades estão se formando de acordo com os interesses chineses, e não com os do Brasil. A China está interessada em soja em grão e minério de ferro, e não em farelo, óleo de soja e produtos semimanufaturados de ferro ou aço; o Brasil está interessado em vender aviões e produtos manufaturados para a China, mas, a China passou, em poucos anos, de importadora a produtora de aviões e o cenário mais provável é que logo estará concorrendo diretamente com a indústria aeronáutica brasileira. Neste contexto, pelo menos em parte, as oportunidades de "negócios da China" com os chineses depende da capacidade das empresas brasileiras de se adaptarem aos termos, condições e exigências derivadas da estratégia nacional de desenvolvimento da China. Para o Brasil, o desafio é internalizar e transformar tais oportunidades em motores do desenvolvimento nacional, independente de terem sido moldadas de acordo com as prioridades chinesas.

As estratégias da China, além de contar com uma cultura milenar de seus implacáveis negociadores, são claras no sentido de aumentar quantitativamente e qualitativamente o seu comércio internacional. Já o Brasil, a despeito do seu potencial qualitativo, parece aceitar passivamente a estratégia chinesa e a especialização assimétrica que se formou na última década. Esta especialização só será modificada se as relações sino-brasileiras transcenderem a esfera comercial e alcançarem o status de relações estratégicas e de longo prazo, em uma cooperação que além do comércio considere também os investimentos, segurança global, meio ambiente e tecnologia. 


\section{China: uma nova fronteira de expansão para a Agricultura Brasileira}

A China desempenha importante papel no mercado mundial de produtos agrícolas, tanto pelo lado da demanda quanto pelo lado da oferta, o que lhe confere grande poder de negociação no mercado mundial. O país é tanto um grande importador de alimentos e matérias-primas in natura como também um grande exportador, notadamente de milho (Gráfico 5), ovos, legumes, produtos madeireiros, aves, entre outros. A estratégia da China tem sido substituir a produção própria de fibras, leguminosas e oleaginosas por importações e alocar terras escassas para a produção de frutas e vegetais ${ }^{11}$. Também tem favorecido a agregação local de valor por meio da agroindustrialização das matérias-primas importadas e da produção local, o que se reflete em baixa participação da China nas importações mundiais de produtos com maior valor, a exemplo de leguminosas, ovos, tabaco (Gráfico 4), e processados. ${ }^{12}$

Nas últimas duas décadas, a relação entre a produção e o consumo chineses foi negativa para a maioria dos produtos, notadamente os não processados ${ }^{13}$, enquanto 0 Brasil ${ }^{14}$ apresentou trajetória oposta.

O gap entre produção e consumo alimentar na China abriu oportunidades para o crescimento do setor agrícola brasileiro, que principalmente nesta última década foi fortemente orientado pelos fluxos comerciais com a China, em particular a soja que tem sido o carro chefe do agronegócio brasileiro.

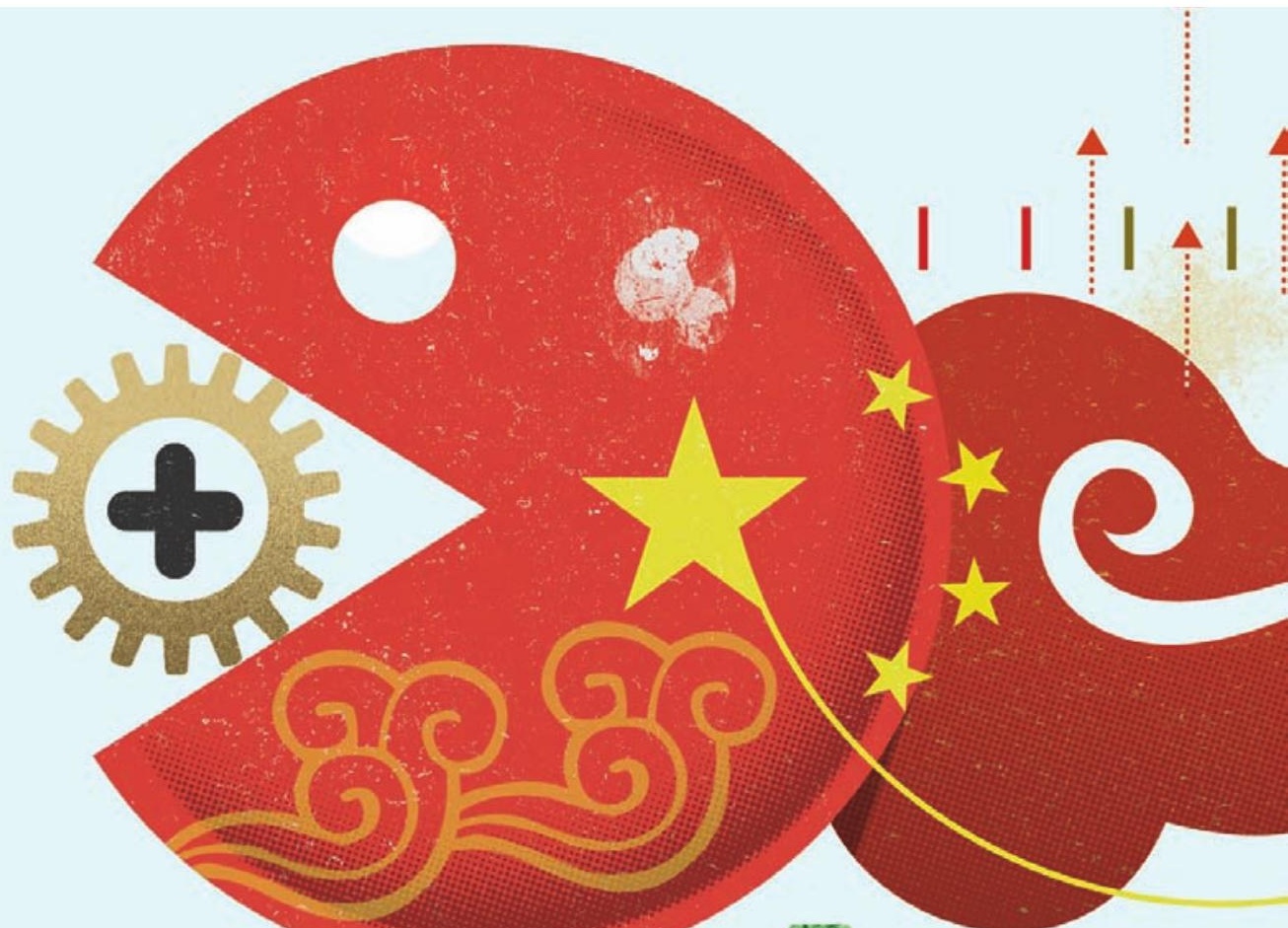


Gráfico 4 - Participações (\%) do Brasil e da China nas importações mundiais de alguns produtos agrícolas selecionados entre os anos de 1990 a 2010 (FAOSTAT, 2012).
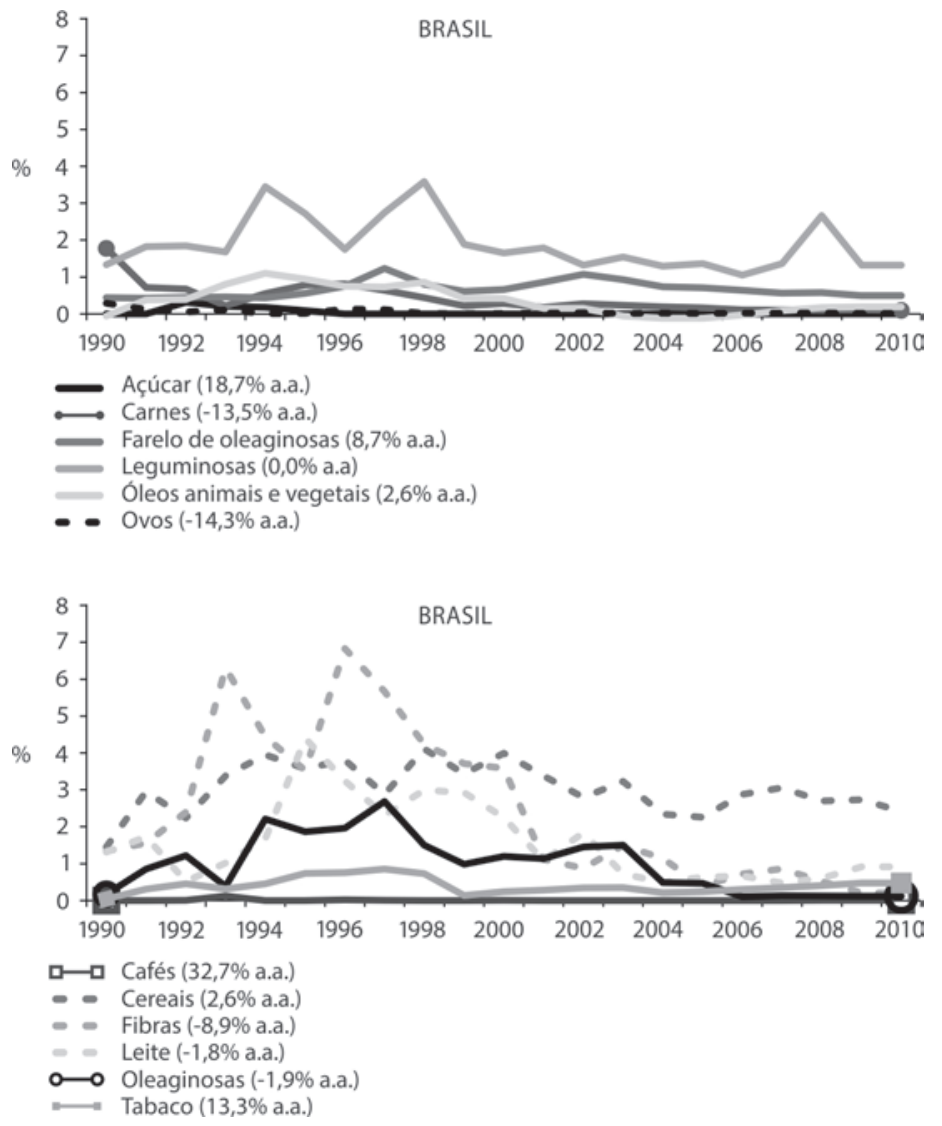

A elevada participação da China na produção agrícola mundial e a estratégia de reforçar a produção mais qualificada (maior valor e agregação local de valor) e de importar produtos agrícolas não processados, como as fibras e oleaginosas, tendem a'desqualificar' as exportações brasileiras. Porém, mantido o desenvolvimento econômico da China e observando a disponibilidade de recursos naturais, notadamente terras agricultáveis e água, a influência chinesa pelo lado da oferta será cada vez mais restrita enquanto os efeitos pelo lado da demanda continuarão crescendo.

O sucesso da agricultura brasileira tem despertado o interesse da China, cujas empresas têm buscado terras no Brasil, predominantemente nos Estados da Bahia e de Goiás, com grandes negócios anunciados pela imprensa, mas sem confirmação oficial. O assunto veio à discussão com a notícia da compra de 100 mil hectares na Bahia pela 
Gráfico 4 (cont.) - Participações (\%) do Brasil e da China nas importações mundiais de alguns produtos agrícolas selecionados entre os anos de 1990 a 2010 (FAOSTAT, 2012).
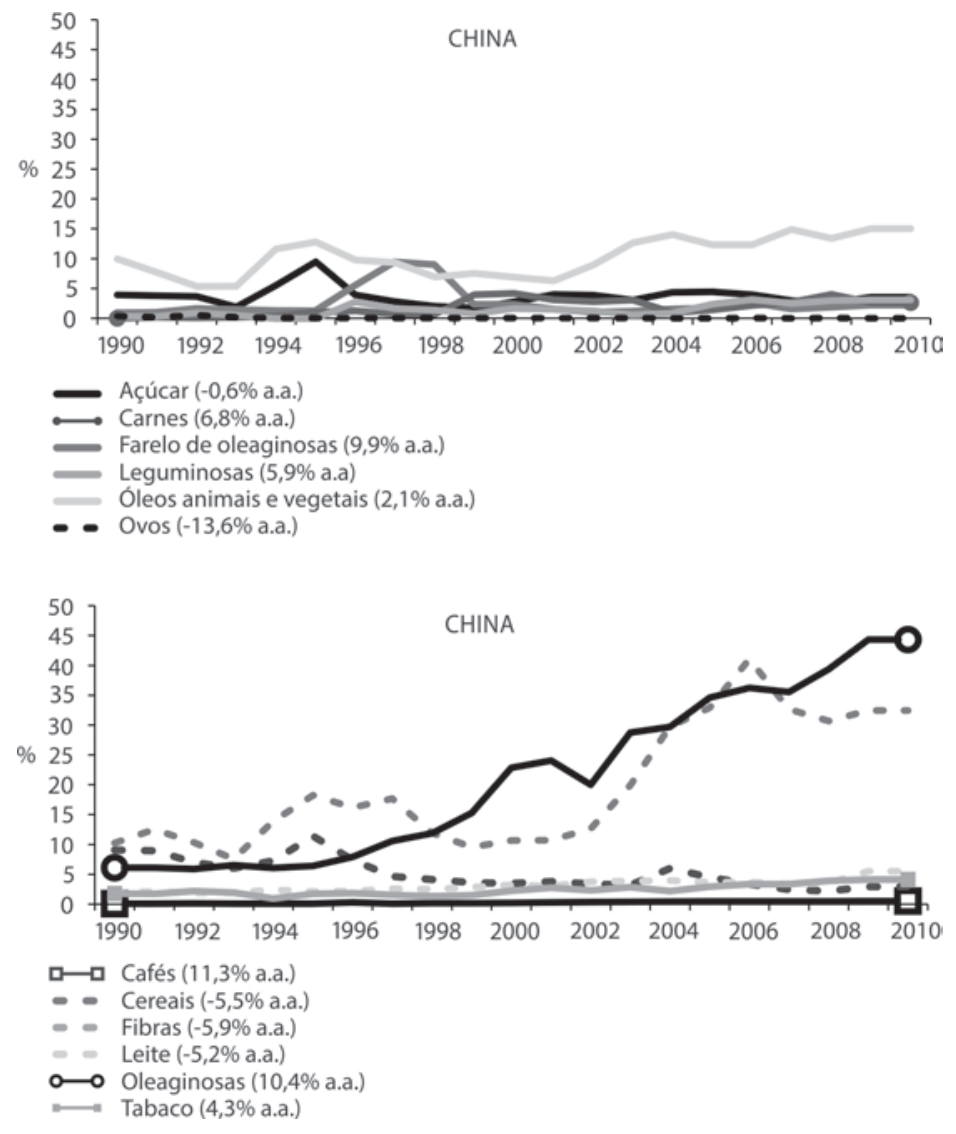

Chongqing Grain Group. Trata-se de um tema de alta sensibilidade política, que desperta polêmicas e já motivou decisões de governo no Brasil, Canadá e Austrália. Parece haver um consenso quanto à especificidade dos investimentos realizados por empresas chinesas controladas pelo poder central, o que os aproxima de investimentos feitos por fundos soberanos, de propriedade de Estados e não de empresas. Esta situação exige uma regulamentação própria e instituições com capacidade para impor limites sem anular as oportunidades associadas aos investimentos estrangeiros que incluem a aquisição de terras. No caso brasileiro, salvo no setor da bioenergia, o estrangulamento não é falta de capital para os investimentos na produção, mas sim de infraestrutura e logística (CNA, 2011; Tenório, 2011), e as empresas chinesas estão se inserindo nestes 
Gráfico 5 - Participações (\%) do Brasil e da China nas exportações mundiais de alguns produtos agrícolas selecionados entre os anos de 1990 a 2010 (FAOSTAT, 2012).
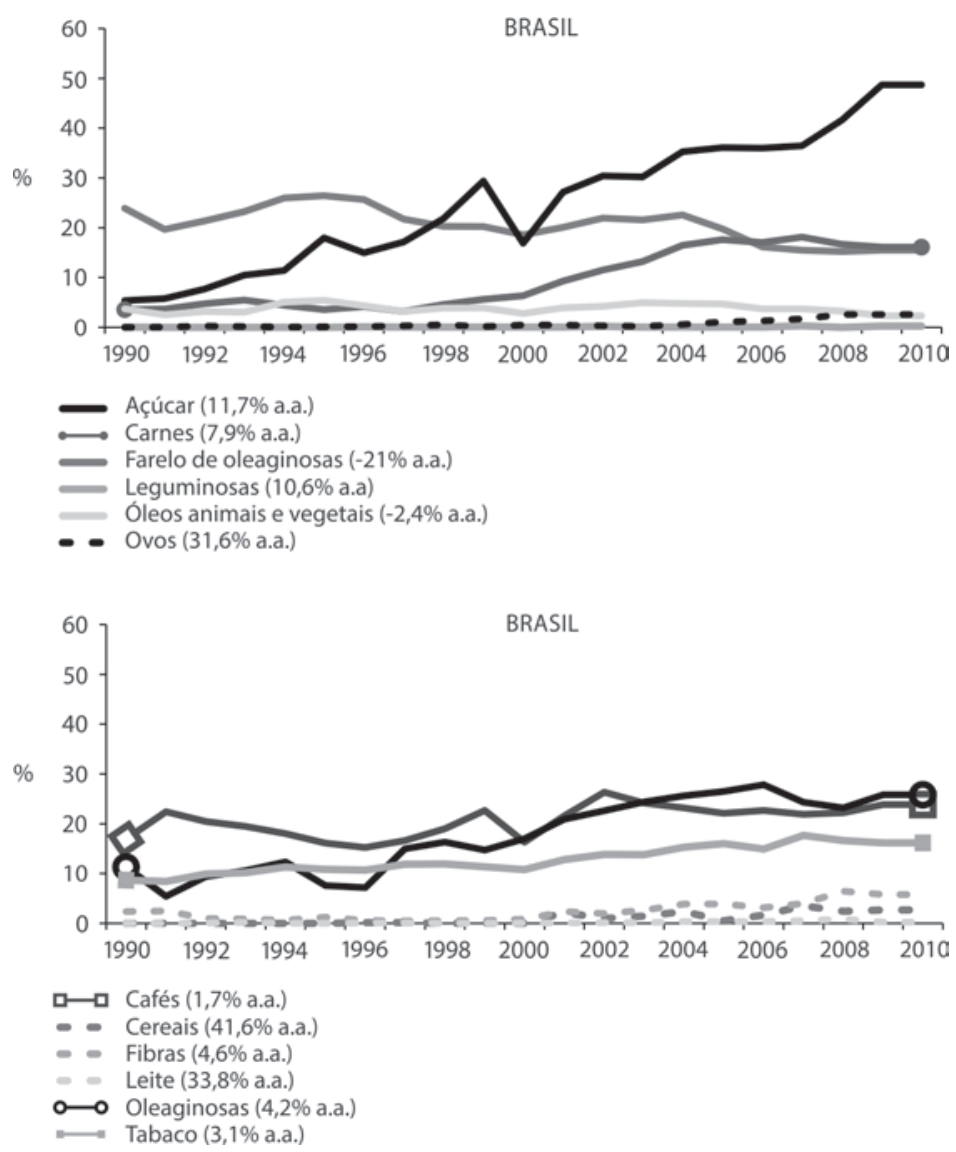

segmentos e no estabelecimento de parcerias para a produção. ${ }^{15}$ Nessa área, o Brasil também carece de políticas e estratégias bem definidas e consistentes para orientar os investimentos externos e fortalecer a posição dos produtores rurais.

Apesar de estar presente em todo o mundo, no período mais recente a agricultura e o agronegócio brasileiros têm respondido fundamentalmente à dinâmica chinesa, expandindo a produção de produtos básicos, como cereais, fibras e oleaginosas, e em menor intensidade a de produtos de maior valor como as carnes e o leite ${ }^{16}$.

As perspectivas da agricultura brasileira no cenário mundial são positivas, pois dispõem de terras para expandir a área agrícola sem comprometer o meio ambiente, e de tecnologias ambientalmente sustentáveis e de bases para manter um processo 
Gráfico 5 (cont.) - Participações (\%) do Brasil e da China nas exportações mundiais de alguns produtos agrícolas selecionados entre os anos de 1990 a 2010 (FAOSTAT, 2012).
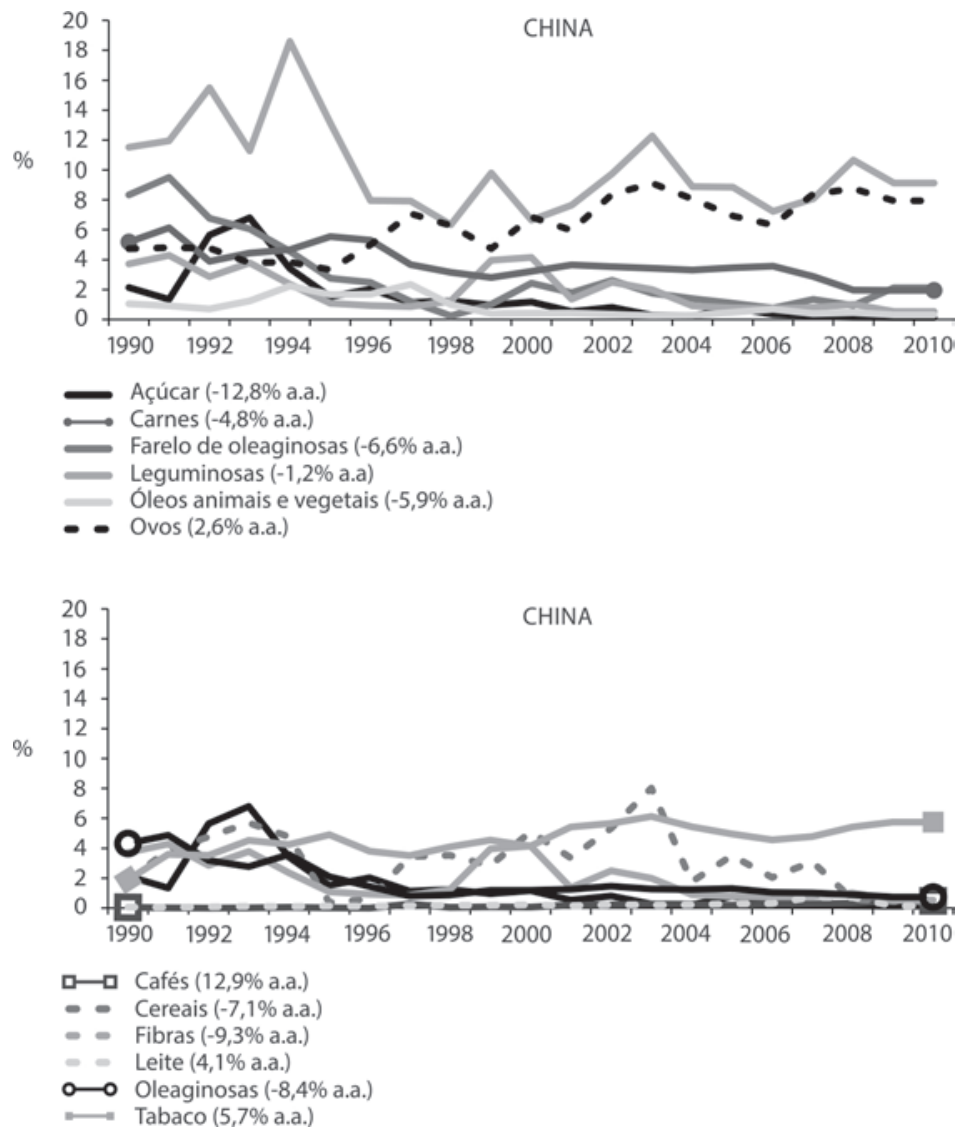

virtuoso de inovação. Nas duas últimas décadas o crescimento da área agrícola foi inferior ao da produção, o que confirma tanto a importância da inovação e aumento da eficiência como o potencial de crescimento da produção, tanto pela expansão da área como pela melhoria do padrão tecnológico. Porém, a participação brasileira nas exportações mundiais de alguns produtos em que a competitividade brasileira é reconhecida, a exemplo do complexo da soja e do suco de laranja, tem se reduzido em consequência do aumento da concorrência internacional e de obstáculos domésticos, como a deficiência logística e as incertezas institucionais. Por outro lado, a diversificação da produção brasileira em produtos processados ficou limitada nas duas últimas décadas devido ao peso da demanda chinesa por matérias-primas e não por produtos finais. 


\section{A expansão chinesa no mundo: o Estado no mercado}

Nas últimas décadas a China acumulou reservas internacionais que, no final de 2011, ultrapassavam US\$ 3 trilhões, mais da metade aplicada em títulos do governo americano com baixo rendimento, e que tem servido como alavanca para os Investimentos Diretos Estrangeiros (IDE) da China no resto do mundo. Embora o IDE China seja recente e pequeno quando comparado ao tamanho da sua economia e aos demais investidores, o rápido crescimento observado nos últimos anos ${ }^{17}$ já colocou o país como uma importante fonte de capital, principalmente para os países pobres e em desenvolvimento.

O IDE chinês sofre forte controle do Estado, tem características peculiares e está intimamente ligado às políticas de crescimento e à geopolítica do país. O controle do Estado é exercido por meio das empresas chinesas - a maioria sob controle direto do Estado -, que embora tenham interesses específicos atuam alinhadas com os objetivos estratégicos definidos pelo Estado. ${ }^{18}$ Até o final de 2004 os investimentos eram dirigidos principalmente para países politicamente estratégicos, como o Sudão e o Paquistão. A compra da Lenovo, unidade de computadores pessoais da IBM, sinalizou um novo direcionador, pautado também pelos interesses de grandes empresas chinesas em expansão no mercado global. Mas a geopolítica continua importante e por isto a China tem espalhado investimentos em todos os continentes, evitando colocar "todos os ovos em uma só cumbuca". Tem investido tanto na Austrália como nos EUA e no Brasil, nos mesmos setores, em uma estratégia clara de controlar a dependência em relação a um único país e desta forma aumentar seu poder de barganha na geopolítica mundial (Rosen e Hanemann, 2011).

Segundo Cheung e Qian (2009) os investimentos da China em países desenvolvidos e em desenvolvimento são motivados por diferentes fatores, que incluem desde conquistar o mercado consumidor para suas exportações e internacionalização das suas empresas até assegurar acesso direto e indireto às fontes de recursos naturais. Os investimentos chineses no exterior também apresentam padrão distinto do seguido pelas corporações multinacionais de estabelecer subsidiárias no exterior: a estratégia das empresas chinesas privilegia fusões e aquisições, revelando pressa para ocupar o espaço e a necessidade de aprendizado para operar em ambientes distintos do chinês.

Observa-se uma ampla distribuição do IDE-China em todo o globo e a preocupação com o fornecimento de energia, produtos minerais e, consequentemente, o transporte desses produtos (Figura 1). Apesar da importância dos investimentos nos EUA e Europa, o mapa revela uma concentração de investimentos no Oriente Médio, Austrália, Brasil, EUA e, mais recentemente, em países Africanos ${ }^{19}$, associados prioritariamente à exploração de recursos naturais ${ }^{20}$.

Entre 2005 e 2011 os IDE da China se concentraram nos setores de energia, mineração, transporte, força, finanças e habitação, e tiveram como objetivos garantir 
tanto o fornecimento de matérias-primas, alimentos e energia como acesso aos mercados consumidores de manufaturados.

Os IDE da China na agricultura (Figura 2), que representam menos de $2 \%$ do total, revelam que neste setor a estratégia é assegurar o abastecimento via comércio e não tanto pela produção direta. Ainda assim, as empresas do agrobusiness chinês estão

Figura 1- Investimentos Diretos no Exterior chineses, em US\$1.000.000,00, mundiais segundo os setores
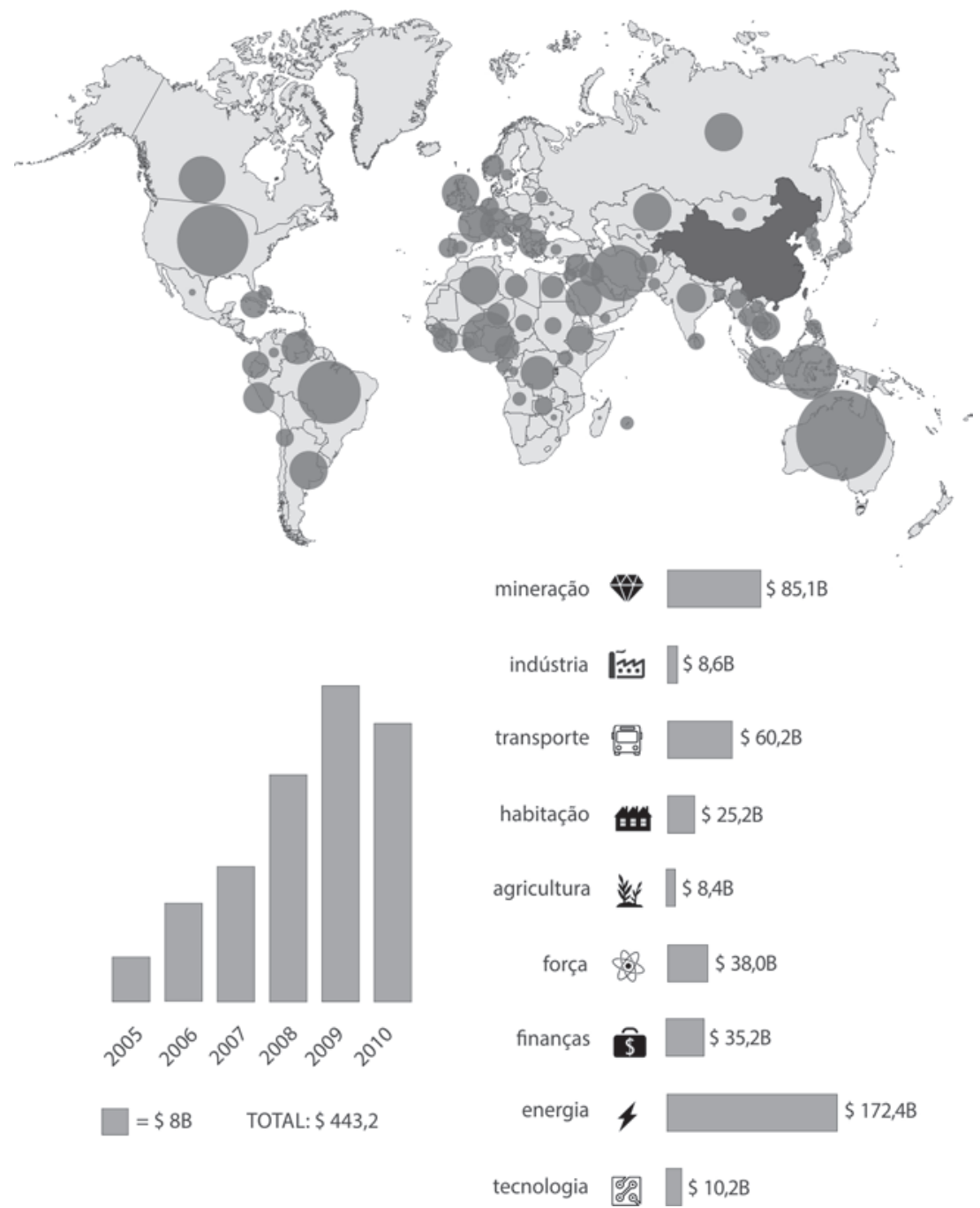
investindo em produção de algodão na África e de arroz na Ásia, e estabelecendo alianças e parcerias na Argentina e no Brasil nos segmentos de algodão, soja e carnes. Também estão adquirindo terras no exterior, principalmente na África, o que tem despertado preocupação quanto aos resultados políticos institucionais dos grandes projetos chineses em países africanos com frágil institucionalidade.

Figura 2 - Investimentos Diretos no Exterior chineses, em US\$1.000.000,00, mundiais segundo os setores de mineração, transportes, agricultura e energia entre os anos de 2005 a 2011 (Heritage Foundation, 2012).
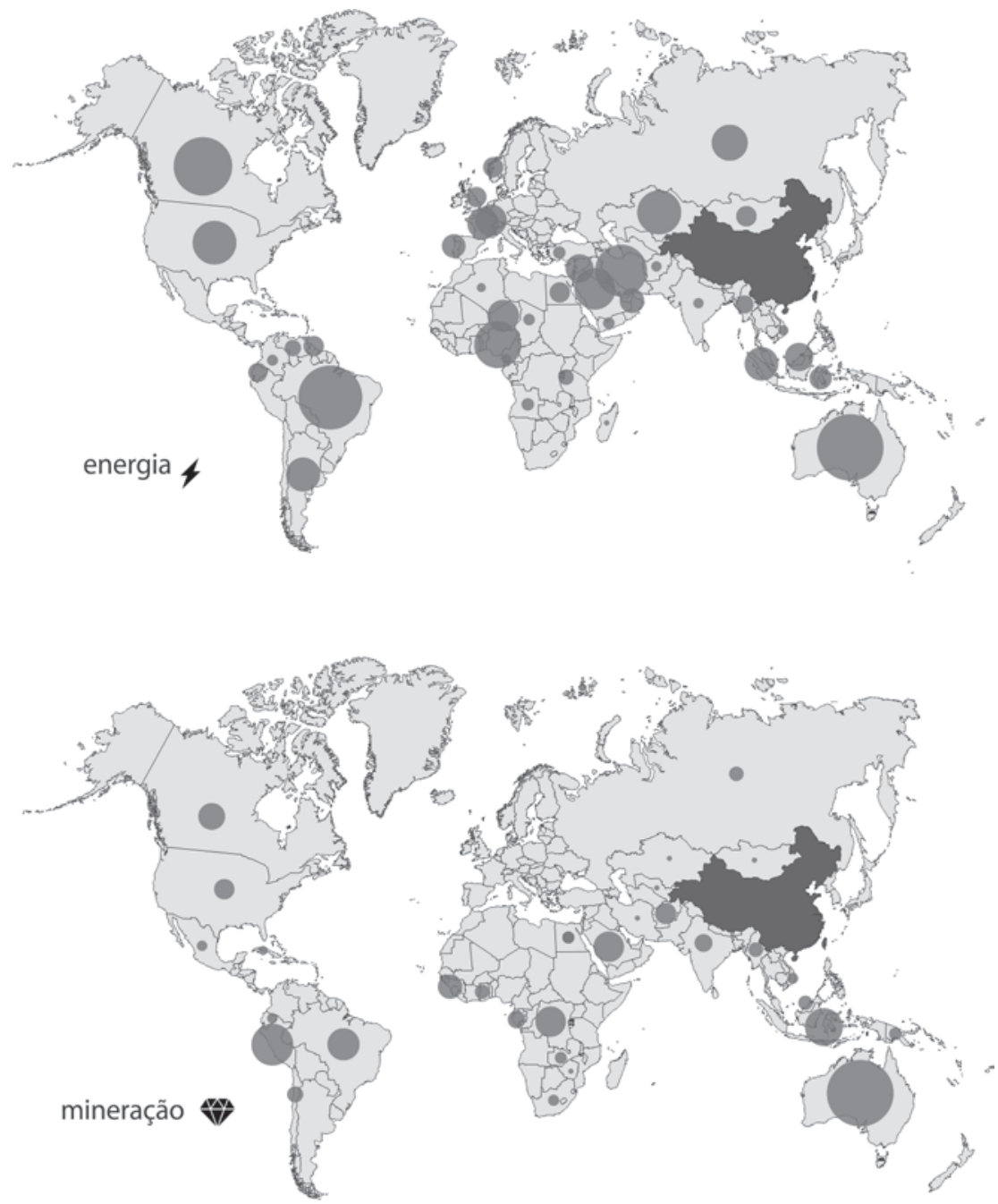
Figura 2 (cont.) - Investimentos Diretos no Exterior chineses, em US\$1.000.000,00, mundiais segundo os setores de mineração, transportes, agricultura e energia entre os anos de 2005 a 2011 (Heritage Foundation, 2012).
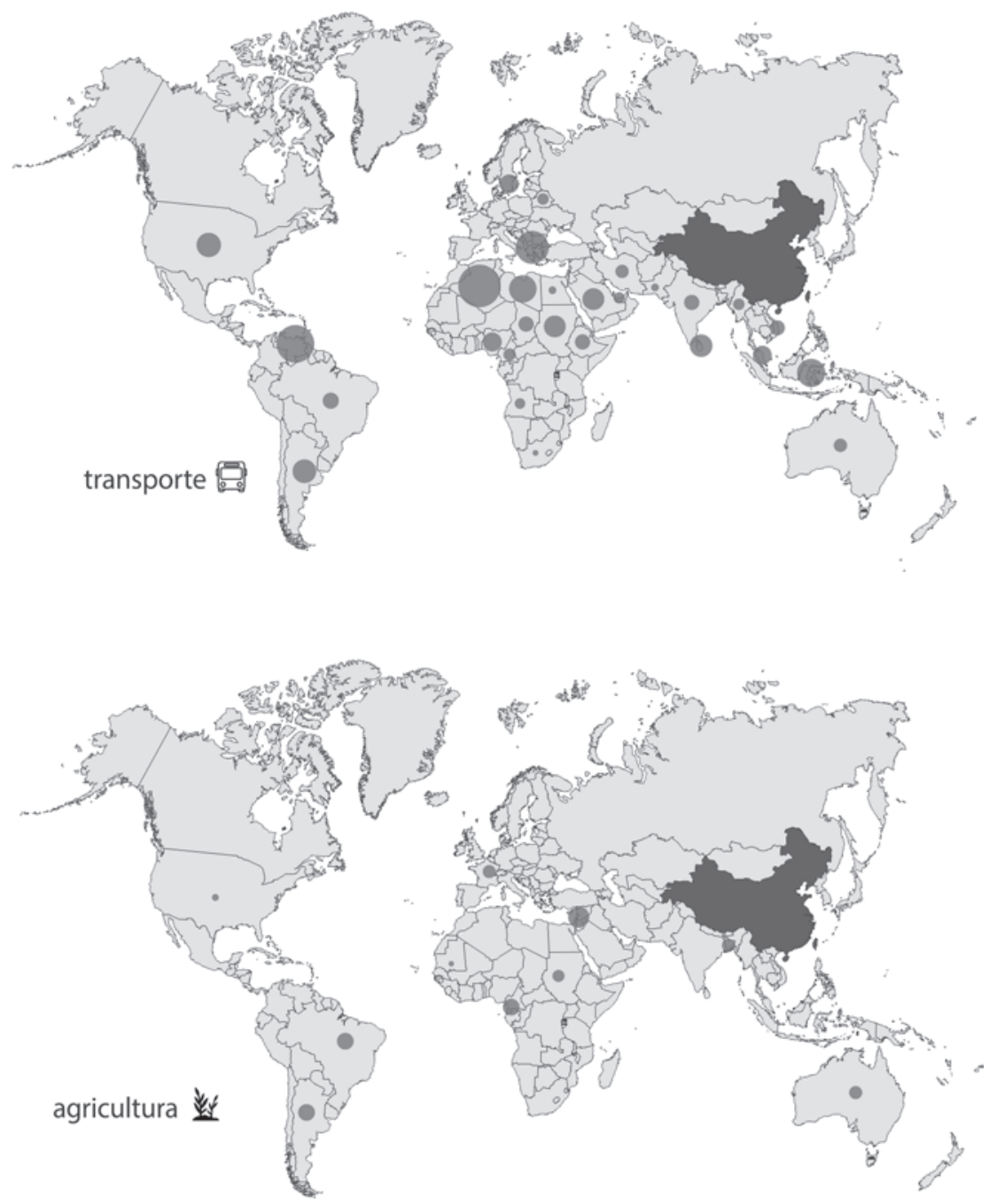
A estratégia de assegurar fornecimento de matérias-primas agrícolas via investimentos em logística, comércio e joint ventures revela a dificuldade das empresas agrícolas chinesas em dominar os processos produtivos em ambientes completamente diferentes, como no Brasil e na África.

Desde 2009 o IDE China no Brasil vem se intensificando e diversificando, mas os investimentos em energia - petróleo e gás - tem se destacado (Gráfico 6), seguido da mineração, agricultura e transporte, principalmente ferrovias e portos. Essa realidade indica a estratégia da China de ter o Brasil em sua carteira de fornecedores de recursos básicos.

A maioria dos IDE China no Brasil ocorre por fusões e aquisições totais e parciais (67\% em 2010), enquanto os investimentos greenfield e as joint venture representaram apenas 23 e 10\%, respectivamente, em 2010. Considerando que mais de $90 \%$ do capital investido no Brasil em 2010 é proveniente de Empresas Estatais Centrais ${ }^{21}$,

Gráfico 6 - Investimentos Diretos no Exterior chineses totais, em US\$1.000.000,00, mundiais e no Brasil e segundo os setores de mineração, transportes, agricultura e energia entre os anos de 2005 a 2011 (Heritage Foundation, 2012).
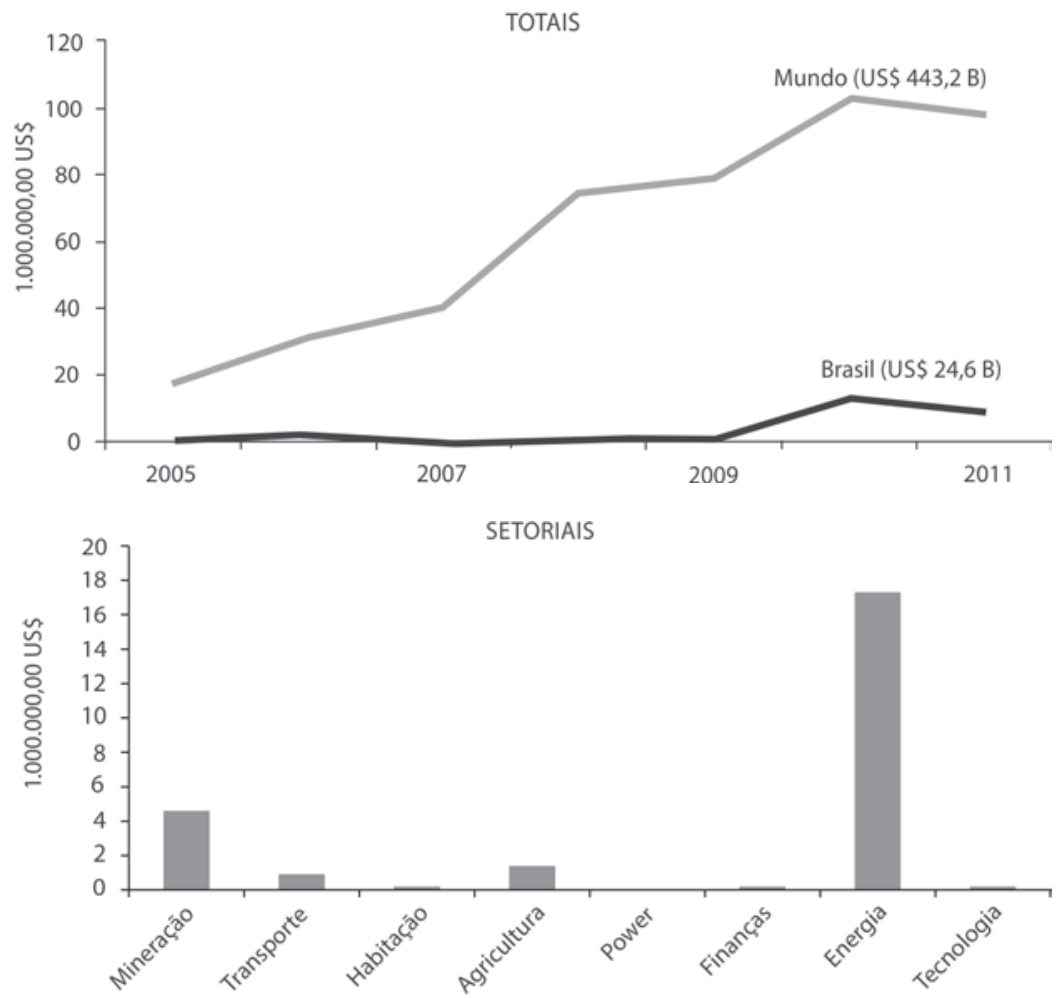
pode se inferir que o interesse da China nestes investimentos não é temporário ou facilmente reversível (Amaral e Castro, 2011).

Com a recente dinamização do mercado de consumo brasileiro, a partir de 2011 estão se multiplicando os investimentos chineses em manufaturas de pequeno e médio porte, notadamente na indústria automobilística, eletroeletrônica e informática. Os investimentos nestes segmentos e outros da indústria deverão crescer no futuro próximo, mas não devem alterar as prioridades da China nos setores de energia, minérios e produtos agrícolas ou comprometer os investimentos no complexo primário exportador brasileiro. O aumento de 70\% e 202\% das exportações de minério de ferro e de petróleo e gás para a China, respectivamente, em 2011, confirmam a posição do Brasil como grande fornecedor de recursos naturais (Amaral e Castro, 2011).

Até o presente, o Brasil se inseriu mais como um fornecedor de matérias-primas que como consumidor de produtos e da tecnologia chinesa (Tabela 1 e Tabela 2) e os IDE China tendem a reforçar essa dinâmica. O IDE China no Brasil já não é desprezível e, por se tratar de investimento de Estado realizado por empresas estatais, merece atenção no sentido de evitar uma exagerada dependência brasileira em relação ao mercado chinês. Mais uma vez, as soluções de mercado podem não atender aos interesses de longo prazo do Brasil, e por isto é preciso negociar politicamente esta parceria e direcionar os investimentos chineses também para aquelas áreas nas quais o Brasil é mais deficitário, como infraestrutura e logística, que poderão alavancar a presença e competitividade da produção brasileira no mercado chinês e mundial. Dado o conhecimento do Brasil em agricultura tropical, mineração, petróleo, gás e biocombustíveis, o Brasil pode ser um importante aliado da China nestes setores.

\section{Considerações fincis}

As relações sino-brasileiras estão, inevitavelmente, inseridas no contexto de mudanças globais, apresentando objetivos comuns de sustentação de projetos econômicos de desenvolvimento. A dinâmica da economia chinesa tem influenciado - e em muitos casos determinado - os movimentos e transformações recentes na economia mundial, formatando os perfis produtivos de muitos países e os fluxos de comércio.

A princípio há complementariedade entre as dinâmicas chinesas e brasileiras, principalmente porque o Brasil tem condições de suprir parte da demanda da China por produtos básicos e enxerga o mercado chinês como uma possibilidade também para as exportações de produtos manufaturados e de maior intensidade tecnológica. Em contrapartida, a China também enxerga as potencialidades do mercado brasileiro em geral e principalmente considera o Brasil como um fornecedor confiável de produtos agropecuários e minerais. Essa aparente complementariedade é assimétrica e limitada aos produtos básicos, pois Brasil e China são concorrentes nos mercados de produtos e serviços de maior conteúdo tecnológico. 
Neste contexto, pelo menos em parte, a vantagem é da China e as oportunidades de "negócios da china" com a China dependem da capacidade de adaptação das empresas brasileiras aos termos, condições e exigências derivadas da estratégia nacional de desenvolvimento da China. Para o Brasil o desafio é internalizar e transformar tais oportunidades em motores do desenvolvimento nacional, independente de terem sido moldadas de acordo com as prioridades chinesas.

A posição da China é inegavelmente melhor que a do Brasil, tanto pelo efeito do tamanho e importância que o país já alcançou no mercado global, retratado pelo comércio exterior e pelos investimentos chineses no exterior, quanto pela coordenação desempenhada pelo Estado chinês. Nesse caso, é importante ressaltar que, independente da influencia exercida pelas empresas estatais no comércio e nos investimentos, o Estado chinês adquiriu poder de coordenação ao proporcionar infraestrutura, educação e inovação.

Dada a crescente importância da China no mundo, é muito positivo que Brasil e China venham construindo, desde 1993, uma parceria estratégica. Éainda mais positivo que, no período recente, esta relação tenha experimentado rápido crescimento. A China é hoje o principal parceiro comercial do Brasil e, por intermédio de suas empresas, a principal fonte de IDE no Brasil. Os acordos já firmados de cooperação e de negócios indicam que a China poderá se tornar um dos mais importantes parceiros do Brasil na área de inovação.

Apesar da distância e das diferenças culturais, a perspectiva de um mundo sinocêntrico não tem por que ser percebida como algo negativo para o Brasil. Ao contrário, apesar das relações hoje bastante assimétricas, o Brasil só tem a ganhar estreitando e aprofundando as relações comerciais, financeiras e político-estratégicas com a China. A assimetria na área da agricultura parece inevitável, mas a consolidação do Brasil como grande produtor de alimentos proporcionada em grande medida pelo comércio com a China pode servir de base para o fortalecimento da agroindústria doméstica, e não para o seu desmantelamento.

O futuro das relações entre o Brasil e a China dependerá da evolução do mercado interno dos dois países, de sua capacidade de superar conjuntamente entraves às relações bilaterais e do desenho de um novo ordenamento internacional, no qual Brasil e China desempenharão papel de crescente importância. Essas são questões complexas e que requerem um enfoque muito mais amplo.

É possível, contudo, esboçar algumas indicações para a análise dessas questões, e tirar algumas conclusões sobre o futuro das relações sino-brasileiras a partir da análise feita acima. Em primeiro lugar o Brasil não tem por que temer a ascensão chinesa; antes, deve compreender o significado das mudanças em curso e utilizá-los a seu favor. É claro que o Brasil está atrasado em relação à China, e que a especialização assimétrica é menos favorável que uma balança comercial mais equilibrada e com mais espaço para as exportações de manufaturados. Mas este espaço tem sido aberto no mercado chinês, e o Brasil não vem aproveitando esta abertura devido a debilidades internas e 
a falta de competitividade da indústria, associada principalmente a custos sistêmicos muito elevados em relação à realidade internacional.

Em segundo lugar, é preciso deslocar a análise do plano comercial para uma visão mais integral da relação com a China, que incorpore as dimensões política, econômica, social e cultural, em um horizonte de longo prazo. Uma análise mais global revela que apesar dos esforços e da busca de autossuficiência alimentar, o abastecimento da China seguirá dependente das importações de alimentos. Esta dependência coloca o Brasil em situação especial, pois além de já ser o maior fornecedor de alimentos para a China é um dos poucos países com condições de continuar expandindo a produção e atender, com segurança, a crescente demanda chinesa. As importações chinesas de soja passaram de 40 para 60 milhões de toneladas em apenas cinco anos. Ao mesmo tempo, as compras de milho, que eram ínfimas há três anos, devem chegar a 7 milhões de toneladas em 2012. Nos últimos doze meses o déficit na cadeia de alimentos com o Brasil chegou a US\$16,036 bilhões. Isso representa muito pouco em relação ao que a China importa (US\$1,798 trilhão), mas a preocupação com a segurança alimentar vem crescendo, tendo em vista as deficiências do país para ampliar a oferta de alimentos bem como a expansão da renda das famílias acompanhada pela crescente urbanização.

A relação sino-brasileira pode avançar bastante, com a exportação de outros produtos, como açúcar, carne e alimentos processados; na margem é possível aumentar a exportação de valor agregado, em especial na cadeia da soja. Além disso, deve-se considerar que devido aos entraves sanitários parte do suprimento de alimentos para a China é intermediada por Hong Kong, como é o caso das vendas brasileiras de aves. Uma nova frente se abre na medida em que empresas brasileiras começam a abrir plantas na China, com o desenvolvimento de centros de distribuição e estratégias mercadológicas específicas para o país. Porém, esses avanços ainda são

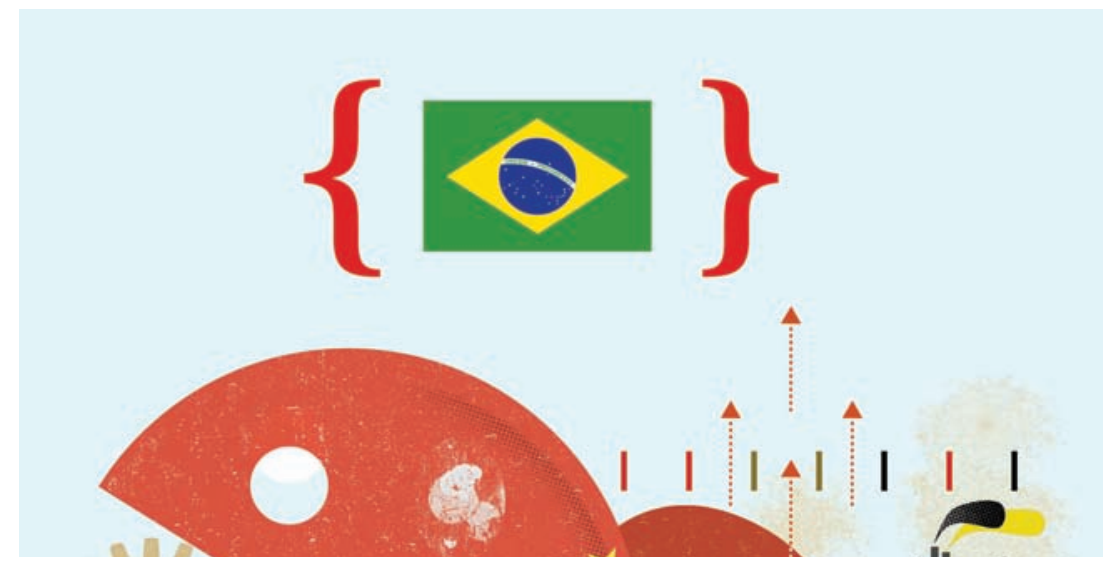


tímidos e se restringem ao campo do comércio e dos investimentos não chegando ao nível estratégico.

O Brasil pode também se beneficiar dos Investimentos Diretos da China no Exterior (IDE) direcionando-os para a construção de infraestrutura que hoje se coloca como um dos maiores obstáculos da competividade brasileira em geral e em particular da agricultura. Para tanto, o Brasil deve se impor regras mais rígidas quanto ao meio ambiente, relações de trabalho e requisitos de transparência, evitando ações predatórias de investimentos voltados para a exploração de recursos naturais.

O clima econômico atual é turbulento para fazer projeções de longo prazo sobre o futuro da economia chinesa, mas é seguro assumir que o seu IDE continuará a crescer e priorizar o acesso à energia e matérias-primas escassas e necessárias para o desenvolvimento chinês. Outras motivações incluem o acesso aos mercados consumidores em expansão, como é o do Brasil. No contexto atual de crise financeira global, a China vem tirando proveito da desvalorização dos ativos e investindo no exterior, ampliando sua influência no mercado global, especialmente em países ricos em recursos naturais e com mercados em expansão. O Brasil se enquadra nas duas categorias, o que facilita os negócios sino-brasileiros e as possibilidades de cooperação bilateral e multilateral estratégica.

A forte participação de empresas chinesas controladas diretamente pelo poder central nos IDE da China é certamente um dado que não pode ser negligenciado, nem mesmo pelo Brasil, que conta com uma institucionalidade democrática bem sólida, diferentemente de vários países africanos nos quais os investimentos chineses parecem estar reproduzindo os "enclaves bananeiros 22" na América Central do século passado. Trata-se de um dado que não será modificado de fora para dentro, e com o qual é necessário conviver e se precaver por meio de investimentos que reforcem as instituições domésticas e competitividade da economia brasileira. Assim, antes de atitudes xenófobas que restrinjam os investimentos estrangeiros, inclusive na compra de terras, é necessário investir em pesquisa, infraestrutura e em políticas públicas consistentes e que fortaleçam a economia brasileira como um todo.

Diante desses desafios o Brasil não pode aceitar passivamente a estratégia chinesa e a relação assimétrica que se estabeleceu e que coloca o país como fornecedor de matérias-primas, que hoje é um "negócio da China" para o Brasil mas que pode se tornar apenas um "negócio para a China" se este padrão continuar contaminando toda a economia brasileira. É preciso negociar contrapartidas, como investimentos em infraestrutura e logística na área de produção de matérias-primas minerais e agropecuárias e em novas indústrias que não sejam apenas montadoras de peças e kits produzidos na China. Além dos interesses complementares na geopolítica, a exemplo da liderança brasileira na América do Sul, o Brasil pode ser um importante aliado da China nos seus investimentos aos países africanos dado o conhecimento do Brasil em agricultura tropical, mineração, petróleo, gás e biocombustíveis. Ou seja, as relações precisam deixar de ser guiadas apenas pelo mercado e passar também pelo crivo das 


\begin{abstract}
negociações políticas e estratégicas que contemplem os interesses de longo prazo dos dois países. Sem isto dificilmente as relações sino-brasileiras se consolidarão como um "negócio da China" depois que passar o boom dos preços das matérias-primas.

A melhor atitude para o Brasil é reforçar o diálogo sobre esses temores e discutir meios para otimizar os investimentos, promover o comércio bilateral de forma mais abrangente e reforçar a cooperação tecnológica. Essas serão as bases para o Brasil aproveitar esse bom momento das relações bilaterais, preparando-se para um futuro virtuoso, o qual, inevitavelmente, passa por sua produção agrícola, um dos principais fundamentos da colaboração sino-brasileira.
\end{abstract}

\begin{abstract}
Notas
1 A expressão "negócio da China" é usualmente utilizada para designar um acordo vantajoso a todos participantes. A concepção desse termo remonta o grande interesse que os comerciantes da Europa tinham em buscar as mercadorias oferecidas pelos chineses e outros povos asiáticos, o que beneficiava tanto a Europa quanto a Ásia.

${ }^{2}$ Ver Quagio (2009) e Kissinger (2011) para uma análise do socialismo chinês.

${ }^{3} \mathrm{O}$ crescimento nominal médio da renda nos últimos 10 anos foi de $13 \%$.

${ }^{4}$ As exportações e as importações da China representaram, na ordem, 10\% e 8\% dos respectivos fluxos mundiais em 2010, ante 4 e 3\%, do ano de 2000 (BACEN, 2011).

${ }^{5}$ Em 2010, apesar de manter participação significativa nas importações mundiais de manufaturados (8,7\%), a China respondeu por 7,6, 25,4 e 7,9\% \% das importações mundiais de produtos agrícolas, minerais e combustíveis.

${ }^{6}$ Em 2010, além de não ter participação significativa nas importações e exportações mundiais de manufaturados, o Brasil respondeu por menos de 5\% das exportações mundiais de produtos agrícolas, alimentos e minerais.

${ }^{7}$ Entre os dez principais produtos, o tabaco total ou parcialmente destalado, é o produto sobre o qual incide o maior imposto de importação (10\%), seguido pelo óleo de soja bruto degomado, pelos couros e peles curtidos e pela flor que são alvos de uma tarifa de 6,33\% (Mortatti 2009).

${ }^{8}$ Dos 150 processos de investigação de dumping abertos pelo Brasil até o fim de junho, 36\% tiveram a China como investigado. No segundo trimestre do ano foram abertas cinco investigações contra a China, sendo a investigação de triangulação (cobertores sintéticos) inédita. Dos casos abertos contra a China até junho de 2011, 30 terminaram com imposição de direitos antidumping, 10 foram concluídos sem imposição de direitos, 10 continuam em investigação e 30 permanecem em vigor $(\mathrm{CNI}, 2011)$.

${ }^{9}$ Miranda et al (2007) ressaltam que: i) a falta de transparência na valoração aduaneira chinesa; ii) a necessidade excessiva de licença de importação específica; iii) a inspeção aduaneira, podendo o produto estar sujeito a diferentes tarifas de importação dependendo do porto; iv) restrições quantitativas; v) proibição de importação de vestuário usado, animais e plantas com doenças ou provenientes de áreas infectadas, qualquer material impresso que possa causar efeitos maléficos aos interesses políticos, econômicos, culturais e morais do povo chinês; e vi) monopólio importador, pois somente as firmas com direito a comercializar podem importar ou exportar bens para a China, sendo que produtos agroindustriais como grãos, algodão e óleos vegetais são importados principalmente por empresas estatais, são instrumentos com potencial de distorcer os mercados quando aplicados pela China.

${ }^{10}$ Nas duas últimas décadas o Brasil tornou-se um importador de equipamentos industrializados, manufaturados e exportador de semimanufaturados, a exemplo de pasta de celulose (4\% das exportações brasileiras em 2010), e commodities, como grãos de soja e minério de ferro, 23 e 43\% das exportações brasileiras em 2010 (Tabela 2).

${ }^{11}$ Apesar da redução da área agrícola cultivada (-0,1\% a.a.) entre os anos de 1990 a 2010, a área cultivada na China nesse período com produtos mais intensivos e/ou de maior valor agregado, a exemplo de frutas (2,2\% a.a.) e vegetais ( $2,6 \%$ a.a.), cresceu em substituição à produtos menos intensivos ou de menor valor como fibras (-0,6\% a.a.), leguminosas (-2,0\% a.a.), oleaginosas ( $-1,1 \%$ a.a.) e raízes e tubérculos (-0,8\% a.a.) (USDA, 2012).
\end{abstract}


${ }^{12}$ Entre os anos de 1990 a 2010 a produção chinesa de milho cresceu 3,1\% a.a., passando de 97.213 .875 toneladas (20,1\% da produção mundial) para 177.540 .788 toneladas ( $21,02 \%$ da produção mundial). As importações chinesas de milho passaram de 5.439 .657 toneladas para 4.676 .032 toneladas, uma redução de 763.625 toneladas (-0,8\%a.a.) o que equivale 1,6\% da produção brasileira no ano de 2010. Já o Brasil, apesar de aumentar a sua produção de 21.347 .800 toneladas no ano de 1990 para 56.060 .400 toneladas em 2010 (4,9\%a.a.), respondeu por apenas 6,6\% da produção mundial de milho no ano de 2010. Quanto ao comércio mundial, apesar do Brasil aumentar em 82,9\% a.a. as suas exportações entre 1990 a 2010, atingindo 7.781 .900 toneladas, o que equivale a 166\% das importações chinesas, em 2010 ainda era importador (FAOSTAT, 2012).

${ }^{13}$ A variação entre os anos de 1990 a 2010 da relação entre a produção e o consumo de produtos como açúcar (0,3 \% a.a.), algodão (-2,2\% a.a.), arroz (-0,3\% a.a.), cafés (0,0\% a.a.), carnes (-1,5\% a.a.), farelo de soja $(-3,8 \%$ a.a.), leite $(0,0 \%$ a.a.), milho (-1,0\% a.a.), soja (-7,7\% a.a.) e óleo de soja ( $2,2 \%$ a.a.) indica que a China tende a manter a produção interna de produtos com maior valor agregado, a exemplo do óleo de soja e o suco de laranja, em detrimento a matéria-prima, no caso a soja em grãos (USDA, 2012).

${ }^{14}$ A variação entre os anos de 1990 a 2010 da relação entre a produção e o consumo de produtos como açúcar (5,1 \% a.a.), algodão (4,0\% a.a.), arroz (1,2\% a.a.), cafés (-1,5\% a.a.), carnes (1,5\% a.a.), farelo de soja $(-3,1 \%$ a.a.), leite $(0,0 \%$ a.a.), milho (1,0\% a.a.), soja (3,3\% a.a.) e óleo de soja $(0,1 \%$ a.a.) indica que o Brasil tende a manter a produção interna de produtos com menor valor agregado, a exemplo da soja em grãos, em detrimento de produtos de maior valor agregado, no caso o farelo e o óleo de soja (USDA, 2012).

${ }^{15} \mathrm{O}$ marco regulatório brasileiro facilita o uso da terra via arrendamento, o que permite explorar sem ser proprietário e abre possibilidades de negócios com os chineses, reunindo empresas brasileiras com experiência e capacidade de administração da produção agropecuária aos capitais chineses.

${ }^{16}$ A área agrícola brasileira cresceu 4\% a.a. entre os anos de 1990 e 2010, notadamente em produtos menos intensivos e/ou de menor valor agregado como cereais $(0,2 \%$ a.a.) e oleaginosas ( $1,0 \%$ a.a.) enquanto reduziu a área de produtos com maior valor agregado, a exemplo de frutas $(-1,4 \%$ a.a.), leguminosas (-2,0\% a.a.), raízes e tubérculos $(-1,1 \%$ a.a.) e vegetais $(-2,0 \%$ a.a.). No caso das fibras, apesar da redução na área (-3,1\% a.a.), o Brasil intensificou sua produção (1,0\% a.a.) pelos ganhos significativos de produtividade (USDA, 2012).

${ }^{17} \mathrm{Em} 2005$, a China ficou em $27^{\circ}$ entre os investidores mundiais e $4^{\circ}$ entre os países em desenvolvimento, excluindo os centros financeiros offshore. Já em 2010 a China ocupava o $22^{\circ} \mathrm{e} 3 \circ$ lugares, respectivamente. Os Investimentos Diretos no Exterior (IDE) cresceram significativamente quando a China passou de US\$ 26,51 bilhões em 2007 para US\$ 55,91 bilhões em 2008, um aumento de mais de $110 \%$. Até o final de 2009, o IDE chinês era de US\$245,75 bilhões e o crescimento mais significativo ocorreu nos últimos 10 anos, passando de menos de US\$ 100 milhões na década de 1980 para US\$ 56,53 bilhões em 2009. Apesar das tendências de crescimento, o IED chinês permanece relativamente pequeno. China, incluindo Hong Kong e Macau, é responsável por apenas 6\% do total global (Salidjanova, 2011).

${ }^{18}$ Apenas quatro empresas (China National Petroleum Corporation, a Sinopec, o fundo soberano o China Investment Corporation (CIC) e a Chinalco) respondem por mais da metade dos investimentos da China no exterior desde 2005. Além disso, os investimentos se concentram em setores nos quais as empresas estatais são obrigadas legalmente a ter maioria, como energia e construção (Heritage Foundation, 2012).

${ }^{19}$ Há cerca de dois anos as atenções chinesas se voltaram para a África em detrimento da América do Sul que recebeu mais de US\$ 60 bilhões até 2009. Já o menor interesse pelos países do Leste Asiático e da Europa se justifica pela reduzida disponibilidade de recursos naturais (Heritage Foundation, 2012).

${ }^{20} \mathrm{Em} 2011$ a África forneceu um terço da energia consumida pela China. Nos últimos cinco anos, a China iniciou uma série de acordos com diferentes países africanos, destacando-se U\$ 938 milhões investidos pela China International Trade andInvestment Corporation em uma fábrica de alumínio no Egito e US\$ 230 milhões em uma mina de ferro-cromo na África do Sul. Durante o Fórum China-África, em 2006, no qual 47 dos 53 chefes de estado africanos participaram, a China concebeu um fundo com mais de US\$ 5 bilhões para investir em infraestrutura e zonas industriais africanas.

${ }^{21}$ O governo chinês faz uma distinção entre as 123 empresas que investem no exterior selecionando um conjunto de 23 empresas classificadas como a "Espinha Dorsal da China". No ano de 2012, dessas 23 empresas oito investiram, ou anunciaram, investimentos superiores a US\$ 21 bilhões no Brasil. São elas: COFCO10 , CNOOC11, Dongfeng Motors, State Grid, China Railway Construction, Baosteel, Sinopec e Sinochem (Amaral e Castro, 2011).

${ }^{22}$ República das bananas, republiqueta de banana ou república bananeira é um termo pejorativo para um país, normalmente latino-americano, politicamente instável, submisso a um país rico e, frequentemente, com um governo corrupto e opressor. Sua economia é em grande parte dependente da exportação de um único produto dependente de recursos naturais, tais como bananas. Normalmente tem classes sociais estratificadas, incluindo uma grande e empobrecida classe trabalhadora e uma plutocracia que compreende as elites de negócios, política e militares (WHITE, 1984). 


\section{Referências bibliográficas}

AMARAL, S.; CASTRO, A. B. (2011). Investimentos chineses no Brasil: uma nova fase da relação Brasil-China. Conselho Empresarial Brasil-China, 52p.

BACEN - BANCO CENTRAL DO BRASIL (2012). Trajetória do Comércio Externo com a China 2000 a 2010. Boletim Regional do Banco Central do Brasil, p.89-92, Abril 2011. Disponível em <http://www.bcb.gov.br/pec/boletimregional/port/2011/04/br201104b1 p.pdf>. Consultado em 29 de março de 2012.

CHEUNG, Y.; QIAN, X. (2009). The Empirics of China's outward Direct Investment. Munich: CESIFO WorkingPaper, n.2621, abril 2009.

CNA - CONFEDERAÇÃO DA AGRICULTURA E PECUÁRIA DO BRASIL (2011). Confederação da Agricultura e Pecuária do Brasil - CNA. ABC, agricultura de baixo carbono: porque investir? Brasília: CNA, 47p.

\section{CNI - CONFEDERAÇÃO NACIONAL DA INDÚSTRIA (2011). Concorrência Brasil x China em} terceiros mercados. São Paulo: Observatório Brasil China, ano 4, n. 3, p.12-16, outubro de 2011.

FAOSTAT (2012). Estatísticas do setor agrícola mundial. Disponível em: <http://faostat.fao.org> Consultado em 29 de março de 2012.

HERITAGE FOUNDATION (2012). China Global Investment Tracker Interactive Map. Disponível em $<$ http://www.heritage.org/research/projects/china-global-investment-tracker-interactive-map ?query=china+global+investment+tracker+interactive+map $>$. Consultado em 29 de março de 2012.

KISSINGER, H. (2011). Sobre a China. Rio de Janeiro: Objetiva, 576 p.

MDIC - MINISTÉRIO DA INDÚSTRIA E COMÉRDIO (2012). Estatísticas do comercio exterior. Disponível em <http://www.mdic.gov.br//sitio/interna/interna. php?area=5\&menu=2477\& refr=576>. Consultado em 29 de março de 2012.

MCCORRISTON, S; MACLAUREN, D. (2007). An assessment of the economic effects of COFCO. International Agricultural Trade Research Consortium (IATRC) on China's Agricultural Trade: Issues and Prospects, Beijing, 8 e 9 de julho de 2007.

MIRANDA, S. H. G. ; OZAKI, V. A.; FONSECA, R.; MORTATTI, C. M. (2007). Perspectives of the bilateral trade China-Brazil: evaluation through a gravity model approach. In: International Agricultural Trade Research Consortium. Summer Meetings, Beijing.

MORTATTI, C. (2009). Determinantes do comércio Brasil-China de commodities e produtos industriais: uma aplicação do modelo VAR. Monografia apresentada à Escola Superior de Agricultura "Luiz de Queiroz" (ESALQ/USP) como requisito para a obtenção do título de Bacharel em Ciências Econômicas. Piracicaba,97p.

OCDE ORGANIZAÇÃO PARA COOPERAÇÃO E DESENVOLVIMENTO ECONÔMICO (2012). OCDE Data Lab. Disponível em: < http://www.oecd.org/statistics>. Consultado em 29 de março de 2012.

QUAGIO, I. (2009). Olhos abertos: a história da nova China. São Paulo: Editora Francis. 272p.

ROSALES, O. (2012). Trade competition from China. Americas Quartely, 26 de Janeiro de 2012.

ROSEN, D.H.; HANEMANN, T. (2011). An American open door? Maximizing the benefits of Chinese Foreign Direct Investment.Center on U.S.-China Relations, Asia Society, Special Report, maio de 2011. 93p.

SALIDJANOVA, N. (2011). Going out: An overview of China's outward Foreign Direct Investment. U.S. - China Economic \& Security Review Commission, USCC Staff Research Report, março, 2011. $41 \mathrm{p}$. 
TENÓRIO, R. (2012). Agricultura - do subsídio à política agrícola. Desafios do Desenvolvimento, ano 8, n.68,p.36-45, 2011. United States Department of Agriculture - USDA. Production, supply and distribution online. Disponível em: <http://apps.fas.usda.gov/psdonline>. Consultado em 29 de março de 2012.

WHITE, R. A. (1984). The morass. United States Intervention in Central America. New York: Harper \& Row, $319 \mathrm{p}$.

WORLD BANK. (2012). Data. Disponível em: <http://data.worldbank.org>. Consultado em 29 de março de 2012. 